\title{
Effect of Chemical Composition of Fine Aggregate on the Frictional Behavior of Concrete-Soil Interface under Sulfuric Acid Environment
}

\author{
Jie Xiao ${ }^{1} \mathbb{D}$, Zhenming $X u^{2}$, Yikang Murong ${ }^{1} \mathbb{D}$, Lei Wang ${ }^{3} \mathbb{D}$, Bin Lei ${ }^{4}$, Lijing Chu ${ }^{5}$, Haibo Jiang ${ }^{1, * \mathbb{D}}$ \\ and Wenjun $\mathrm{Qu}{ }^{6}$
}

Citation: Xiao, J.; Xu, Z.; Murong, Y.; Wang, L.; Lei, B.; Chu, L.; Jiang, H.; $\mathrm{Qu}, \mathrm{W}$. Effect of Chemical Composition of Fine Aggregate on the Frictional Behavior of Concrete-Soil Interface under Sulfuric Acid Environment. Fractal Fract. 2022, 6, 22. https:// doi.org/10.3390/fractalfract6010022

Academic Editor: Norbert Herencsar

Received: 27 November 2021

Accepted: 25 December 2021

Published: 31 December 2021

Publisher's Note: MDPI stays neutral with regard to jurisdictional claims in published maps and institutional affiliations.

Copyright: (C) 2021 by the authors. Licensee MDPI, Basel, Switzerland. This article is an open access article distributed under the terms and conditions of the Creative Commons Attribution (CC BY) license (https:// creativecommons.org/licenses/by/ $4.0 /)$
1 School of Civil and Transportation Engineering, Guangdong University of Technology, Guangzhou 510006, China; xiaojie2017@gdut.edu.cn (J.X.); 2112109015@mail2.gdut.edu.cn (Y.M.)

2 Guangzhou Communication Design Institute Co., Ltd., Guangzhou 510030, China; 63504106@vip.163.com

3 College of Materials Science and Engineering, Xi'an University of Architecture and Technology, Xi'an 710055, China; wanglei535250684@xauat.edu.cn

4 Guangzhou Krystic Material Technology Co., Ltd., Guangzhou 510940, China; zhurenweile@163.com

5 Guangzhou Urban Planning \& Design Survey Research Institute, Guangzhou 510060, China; churaul@126.com

6 College of Civil Engineering, Tongji University, Shanghai 200092, China; quwenjun.tj@tongji.edu.cn

* Correspondence: hbjiang@gdut.edu.cn

\begin{abstract}
Through direct shear tests, this paper aimed to research the effect of fine marble aggregate on the shear strength and fractal dimension of the interface between soil and concrete corroded by sulfuric acid. More realistic concrete rough surfaces than the artificially roughened surfaces were formed by immersing four concrete plates in plastic buckets filled with sulfuric acid for different periods of time. The sand was adopted to imitate the soil. 3D laser scanner was employed to obtain the digital shapes of concrete plates subjected to sulfuric acid, and the rough surfaces were evaluated by fractal dimension. Large direct shear experiments were performed to obtain the curves of the interface shear stress and shear displacement between sand and corroded concrete plate. The method of data fitting was adopted to calculate the parameters of shear strength (i.e., friction angle and the cohesive) and the parameters of the Clough-Duncan hyperbolic model. The results indicated that as the corrosion days increased, the surface of the concrete plate became rougher, the surface fractal dimensions of the concrete corroded by sulfuric acid became bigger, and the interface friction angle became greater. The friction angle of the interface and the fractal dimensions of the surface of the concrete plate containing crushed gravel and marble sand were smaller than that of the concrete plate containing crushed gravel and river sand.
\end{abstract}

Keywords: direct shear test; sulfuric acid; fine marble aggregate; fractal dimension; 3D laser scanning technique

\section{Introduction}

The research on the shear performance of interface between soil and structure has long received significant attention due to its common existence in geotechnical engineering including soil-pile foundation interaction, soil-retaining wall contact, soil-tunnel contact, and so on [1-3]. The shear performance of interface between soil and structure could be researched by performing in situ experiments and reduced model in the laboratory. The reduced model experiments between soil-structure interface, including direct shear experiments, simple shear experiments, and ring shear experiments [4-15], have the advantages of repeatability and parameter controllability. Since the direct shear test method was simple and the results were reasonable accurate, the direct shear test was usually selected to study the performance of the interfaces between soil and structure [16-20]. Previous studies have indicated that the shear strength of the soil-structure interface was influenced by the roughness of the structure interface, normal stress, water content of the soil, soil type, relative 
density, and other factors [21]. Potyondy [21] noted that the roughness of the interface was one of the major factors in determining soil-structure interface shear resistance as early as 1961. Uesugi et al. [22] performed simple shear experiments to study the shear performance of the steel-sand interface and they put forward the surface roughness as a key factor affecting the interface shear mechanical property. In order to investigate the soil-structure interface property at different roughnesses, three problems were required to be considered: the method for producing the rough surface, the method for measuring the rough surface, and the method for evaluating roughness.

First of all, regular, artificial rough surfaces were usually adopted by most of the researchers to simulate the rough structure interface in engineering practice. Sharma et al. [23] glued fine and medium sand on the smooth mild steel surface to produce two types of rough surfaces. Taha et al. [24] obtained two different rough surfaces by using sand blasting and disc grinding the concrete specimens. Qian et al. [25] employed three ribbed slabs made of concrete with rib spacing of $125 \mathrm{~mm}, 170 \mathrm{~mm}$, and $250 \mathrm{~mm}$ to imitate the influence of ribs on the interfacial resistance between helical pile and soil. Kou et al. [26] adopted three different numbers of grooved trenches (e.g., 0, 7, and 9 trenches) to achieve different surface roughness; the cross-section of each trench was an isosceles triangle and these grooves have cross-sections of isosceles triangles with the height of $1.0 \mathrm{~mm}$ and vertex angle of $45^{\circ}$. Zhao et al. [27,28], Zhang et al. [29], Li et al. [30], Su et al. [31], Hu et al. [5], Chu et al. [32], and Wang et al. [33] employed concrete serration slabs or steel serration slabs to simulate structural surfaces with different roughness. Chen et al. [34] adopted concrete plates with different numbers of grooved trenches to obtain five different target roughness values and these grooved trenches have semicircular cross-sections with a diameter of $5 \mathrm{~cm}$. Since most of the structure surfaces were generally random or highly irregular, the artificial regular surfaces cannot reflect the real performance of a random and irregular interface in a corrosive environment. In this paper, four concrete slabs which were soaked in plastic buckets filled with sulfuric acid for four different periods of time were utilized to obtain four various concrete surface morphologies.

Secondly, the Sand Patch Test was the simplest quantitative method due to its low cost and convenient operation. However, the Sand Patch Test method was only applicable to horizontal structure surfaces and the parameters were not sensitive to microscopic texture characteristics [35]. Then, another method was to employ the Mechanical Stylus to measure and evaluate the roughness of the surface in the laboratory. However, there were some shortcomings in this approach. First, the size of the test specimen would affect the measurement accuracy, and second, the surface of the test piece may be destroyed during the testing process [36]. For the last few decades, due to its merits of high measurement precision, good portability, nondestructive, and noncontact properties, the laser scanning technology has been widely used in medical, aerospace, automotive, civil engineering, historical architectural protection, and other fields [37,38]. In this study, 3D laser scanner was adopted to obtain the digital models of concrete plates corroded by sulfuric acid.

Thirdly, the roughness evaluations in the early studies were qualitative, where surfaces were divided roughly into smooth and rough kinds [24,25]. The advantage of this method was fast and simple, but the disadvantage of this approach was that the result was subjective. In order to better investigate the effect of surface roughness on the shear performance of the interface, it is necessary to quantitatively define the roughness based on the surface profile. Many parameters have been proposed for evaluating the concrete surface roughness. The parameter $\mathrm{Ra}$, which was defined as the average deviation of a surface profile relative to its average line, was widely used in surface roughness quantification due to its simplicity [39]. Rmax [28-30] was proposed by Yoshimi and Kishida [40] and its definition was the maximum vertical distance between the highest point and the lowest point along the section line on a standard length, while Rn [5,31] was proposed by Uesugi and Kishida [41] and was expressed as Rmax divided by the mean particle diameter (D50). However, Rmax and Rn could not reflect the partial distribution and local changes of the surface profile [42]. The application of fractal dimensions to the eval- 
uation of the rough surface became more and more popular [43-46] and several studies concluded that the fractal dimension could be applied successfully in evaluating the resistance of steel corrosion [47,48], pore evolution in concrete [49], and evolution of fracture in rock surface $[50,51]$. The calculation of fractal dimension had nothing to do with the sampling range and the resolution of roughness measuring tool [52]. In this study, the fractal dimension was used to assess the roughness of the surface.

Concrete has become the most widely used material in the world [12-14,53-65]. Since concrete is always alkaline, the service life of concrete structures would be shortened when exposed to acidic conditions. Sulfuric acid is one of the most common and harmful acid environments encountered in engineering practice. Sulfuric acid could be produced by sulfur compounds oxidation (e.g., pyrite [66], sulfur dioxide [67,68]) or bacterial activities $[69,70]$. In terms of the mix proportion of concrete, the fine material accounts for about $25 \%$ of the total weight of concrete. The aggregate could be divided into calcareous aggregate and siliceous aggregate according to their chemical composition. The calcareous aggregate is mainly composed of calcium carbonate which is more susceptible to acid attack. However, the siliceous aggregate id mainly composed of silicon dioxide which does not react well with acids. The influence of aggregate chemical composition on concrete sulfuric acid resistance was investigated by some researchers. Chang et al. [71] studied the sulfuric acid resistance of different concrete mixtures containing calcareous limestone aggregates and siliceous aggregates to a $1 \%$ sulfuric acid solution over 168 days. The results indicated that mixtures prepared with calcareous limestone aggregates had a better performance in the $1 \%$ sulfuric acid solution because only cement hydration products in silica aggregate concrete can react with acid, whose neutralization ability during acid attack was quite limited. However, in the calcareous limestone aggregates concrete, calcareous limestone aggregates are $99.5 \%$ acid soluble, which means that calcareous limestone aggregates would lower the concentration of the acid near the surface of the concrete and would lower the deterioration rate. According to the report, the service life of the sewer pipes containing limestone aggregates was 3-5 times bigger than that containing siliceous aggregates in South Africa [71]. Belie et al. [72] carried out chemical and microbiological experiments to assess the resistance of concrete containing slag cement, limestone aggregates, and siliceous aggregates and pointed out that degradation is most affected by the type of aggregate. Concrete containing siliceous aggregates presented a larger degradation depth than the concrete containing limestone aggregates which could create a local buffer environment to protect the cement slurry. Hughes et al. [73] compared the resistance to the sulfuric acid attack of similar concretes containing either limestone or siliceous aggregate and found that the concrete containing limestone aggregates presented a smoother surface with no detritus and the concrete made with siliceous aggregates formed a very irregular surface with considerable aggregate detritus. Xiao et al. [74] investigated the influence of sulfuric acid erosion on the interface between concrete plates and sand, which were soaked in sulfuric acid for four different periods of time. In their studies, the fine aggregate cast in concrete plates was river sand, which belonged to siliceous aggregates. However, the effect of sulfuric acid erosion on the interface between concrete plates and sand incorporating fine marble aggregates is not clear yet.

In this paper, the rough surface of the concrete plate was formed by sulfuric acid corrosion, and the theory of fractal geometry and laser scanning technique were separately adopted to calculate roughness evaluation parameters and measure the rough surface. This study aimed to perform the direct shear experiment to investigate the influence of fine marble aggregate on the frictional behavior of soil-pile interfaces when the concrete was under sulfuric acid environment, which had infrequently been reported in the past. The results in the paper would become a reference for diagnosing, evaluating, and analyzing the interface performance between soil and concrete materials corroded by sulfuric acid. 


\section{Experiment Program}

\subsection{Large Direct Shear Experiment Equipment}

The large direct shear equipment adopted in this study was designed and fabricated in Tongji University (SJW-200) [18]. Figure 1 depicts a schematic diagram and photograph of the large direct shear device. The traditional direct shear instrument has some disadvantages, such as drainage not being able to be effectively controlled, the void water pressure not being measureable, the shear plane being fixed, its area decreasing with the increase of shear displacement, the distribution of shear force on the shear plane not being uniform, and the middle being small and the edge large. However, since the direct shear test method was simple and the results were reasonably accurate, the direct shear test was usually selected to study the performance of the interfaces between soil and structure. This paper selected dry sand as the soil sample, and the maximum displacement was only $5.83 \%$ of the shear box length of $600 \mathrm{~mm}$, and the area due to shear was relatively small.
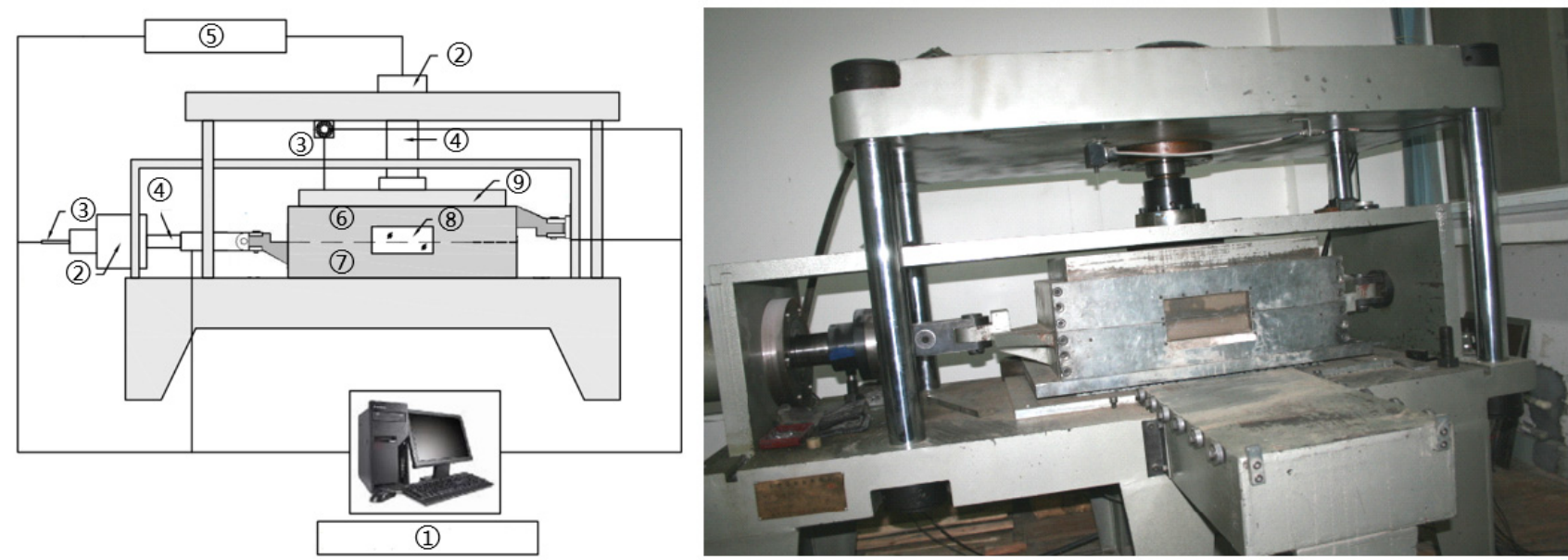

(1)Control and data acquisition system, (2)load cell, (3)linear variable differential transformer (LVDT), (4) actuator, (5)ydraulic system, (6)upper shear box, (7)lower shear box, 8)observation window (9)loading plate

Figure 1. The large direct shear device in Tongji University (SJW-200).

The device was composed of three main components: measuring and controlling component, a hydraulic servo component, and loading actuators in the loading component. The major technical indicators were shown in Table 1 . The inner sizes of the shear box at the bottom is $600 \mathrm{~mm} \times 400 \mathrm{~mm} \times 100 \mathrm{~mm}$ as is the shear box at the top. During the shearing, the shear box at the top which is full of sand is fixed, and the shear box at the bottom which is filled up with concrete is able to move horizontally by a horizontal loading actuator to simulate pile movement through the soil. In order to look into the shear deformation of the soil layers, a window made of plexiglass was provided in the middle of the lower and upper shear box. Hydraulic actuators were adopted to apply horizontal and vertical displacement loads. Two load cells were used to measure the shear stress and vertical stress during shearing. Two linear variable different transformers (LVDTs) were adopted to monitor horizontal and vertical displacement. A computerized data logging system was used to collect all recorded data at 0.4 seconds intervals.

Table 1. Major specialized indicators of the large direct shear experiment equipment.

\begin{tabular}{ccccccc}
\hline \multirow{2}{*}{$\begin{array}{c}\text { Shear Box Net } \\
\text { Size/mm }\end{array}$} & \multicolumn{2}{c}{ Maximum Load/kN } & \multicolumn{2}{c}{ Maximum Displacement/mm } & & Shear \\
\cline { 2 - 5 } & $\begin{array}{c}\text { Normal } \\
\text { Direction }\end{array}$ & $\begin{array}{c}\text { Tangential } \\
\text { Direction }\end{array}$ & $\begin{array}{c}\text { Normal } \\
\text { Direction }\end{array}$ & $\begin{array}{c}\text { Tangential } \\
\text { Direction }\end{array}$ & Accuracy in \\
Rate/(mm/min) & Measurement/\% \\
\hline $600 \times 400 \times 200$ & 200 & 200 & 50 & 150 & $0.1-50$ & 0.5 \\
\hline
\end{tabular}




\subsection{Concrete Plate}

In this study, normal Portland cement P.II $52.5 \mathrm{R}$ was used; its 28-day compressive strength was $55.3 \mathrm{Mpa}$, the crushed gravel had sizes of 5-25 mm, and its apparent density was $2644 \mathrm{~kg} / \mathrm{m}^{3}$. Cement and crushed gravel were supplied by Suzhou Sanhe Pipe Pile Company of China. Marble sand, which was adopted as fine aggregates, was crushed into particles by a crusher from a block of natural marble rock. The fineness modulus of marble sand was 2.61 and the water absorption of marble sand was $1.79 \%$ and the apparent density of marble sand was $2630 \mathrm{~kg} / \mathrm{m}^{3}$. The water-to-cement ratio was set at 0.45 (by weight) and water content per cubic meter of concrete was $205 \mathrm{~kg}$, cement $456 \mathrm{~kg}$, fine aggregate $522 \mathrm{~kg}$, and coarse aggregate $1162 \mathrm{~kg}$. The structural material was concrete slab with thickness of $50 \mathrm{~mm}$, width of $400 \mathrm{~mm}$, and length of $600 \mathrm{~mm}$. A total of four identical concrete slabs were poured. Three concrete slabs were completely immersed in sulfuric acid solution after 28 days of curing, as shown in Figure 2. According to previous studies, the sulfuric acid solution $\mathrm{pH}$ value in the plastic vessel was $0.95[71,75]$. The rough surfaces of concrete slabs were generated by completely soaking for $0,31,93$, or 154 days (the actual soaking periods of time) in sulfuric acid solution with $\mathrm{pH} \approx 0.95$. A portable $\mathrm{pH}$ meter with an accuracy of 0.01 was employed to measure the $\mathrm{pH}$ value of the solutions during 154 days of the testing period. Concentrated sulfuric acid of $98 \%$ mass fraction was added every day to maintain the $\mathrm{pH}$ value fluctuating within the set value 0.95 . After the concentrated sulfuric acid was added daily, the solution was stirred gently to lower differential concentrations of the sulfuric acid in the solution container. The sulfuric acid solution was replaced once a month.

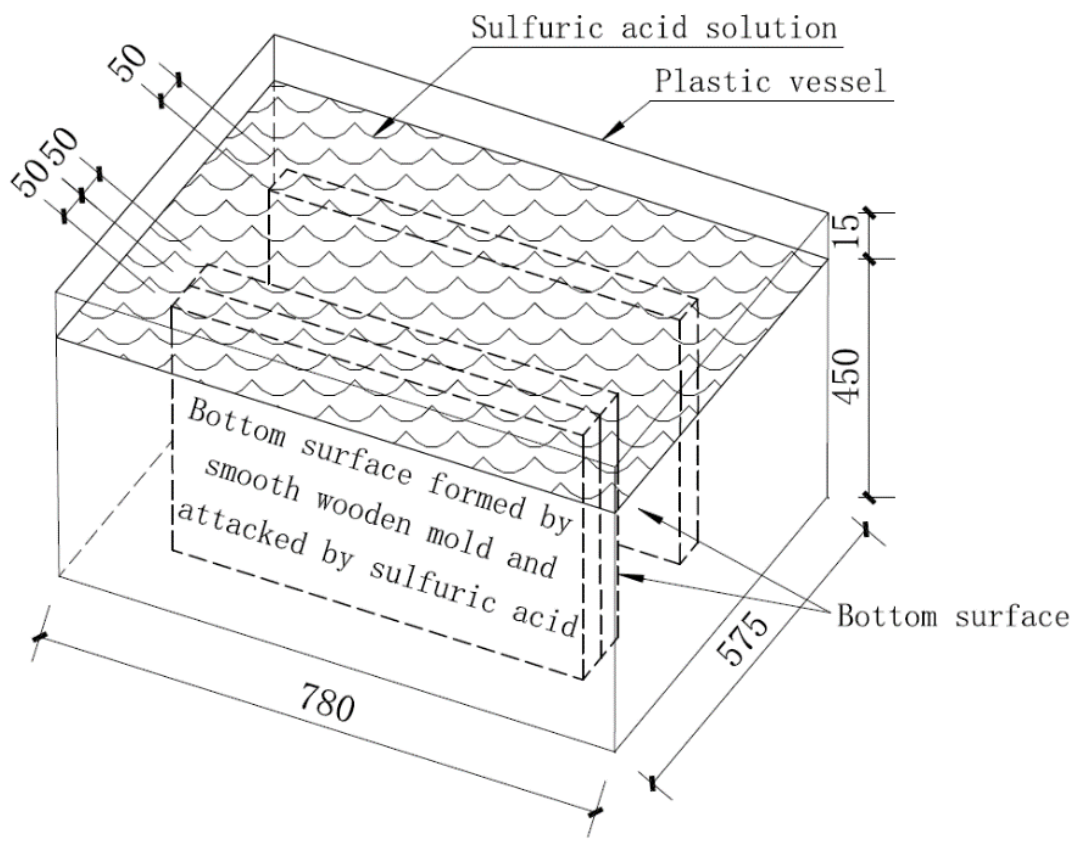

Figure 2. Three concrete plates arrangement in the plastic vessels (mm).

\subsection{Soil Sample}

Since the research objective of the paper was to explore the effect of the surface roughness of the concrete pile formed by sulfuric acid on the interface behavior between soil and corroded pile. For the purpose of eliminating the effect of soil samples variation on the research of the structure-soil interface, this paper kept the soil samples unchanged and the sand was selected as soil samples to perform the direct shear test because the nature of sand soil is more uniform and stable. The sand was dried in the sun, such that the effect of saturation degree was ignored. Figure 3 shows the distribution curve of the sand and Table 2 shows the fundamental physical properties of the sand. 


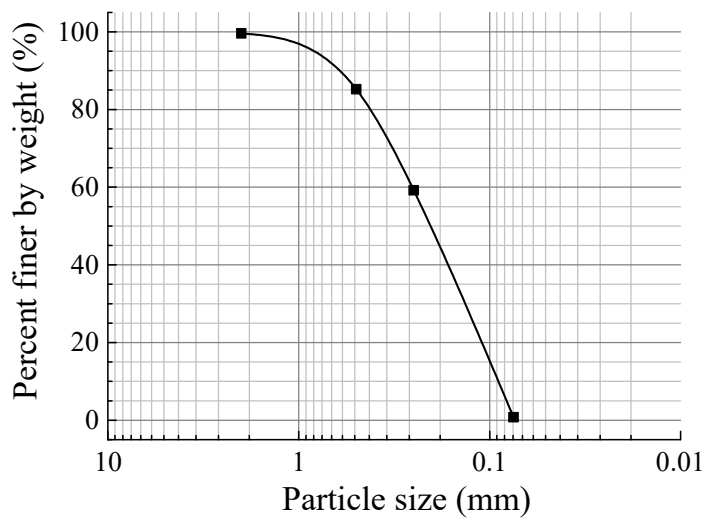

Figure 3. The distribution curves of the sand particle.

Table 2. Fundamental material properties of the sand.

\begin{tabular}{|c|c|c|c|c|c|c|c|}
\hline \multirow{2}{*}{$\begin{array}{l}\text { Specific } \\
\text { Gravity }\end{array}$} & \multirow{2}{*}{$\begin{array}{c}\text { Water } \\
\text { Content } / \%\end{array}$} & \multicolumn{2}{|c|}{ Density/g/cm ${ }^{3}$} & \multicolumn{2}{|c|}{ Void Ratio } & \multirow{2}{*}{$\begin{array}{l}\text { Coefficient of } \\
\text { Uniformity } C_{u}\end{array}$} & \multirow{2}{*}{$\begin{array}{l}\text { Coefficient of } \\
\text { Curvature } C_{c}\end{array}$} \\
\hline & & $\rho_{\max }$ & $\rho_{\min }$ & $e_{\max }$ & $e_{\min }$ & & \\
\hline 2.58 & 0.04 & 1.726 & 1.453 & 0.776 & 0.495 & 2.78 & 1.00 \\
\hline
\end{tabular}

\subsection{The Morphology of Corroded Surface Acquired by Laser Scanning Technique}

In recent decades, the laser scanning technology has been widely applied in medical, aerospace, automotive, civil engineering, historical architectural protection, and other fields due to its merits of high measurement precision, good portability, nondestructive, and noncontact properties. In this study, digital models of the corroded concrete plates' rough surface were obtained with the 3D laser scanning technology. The hand-held 3D laser scanning device called T-SCAN CS was adopted, which was from German Steinbichler Optoelectronics Technology Co., Ltd., as shown in Figure 4. The three-dimensional coordinates of every point on the rough surface of corroded concrete plates were obtained based on the principle of triangulation techniques and the method of light sweeping. Then, the 3D coordinates of every point on the corroded surfaces of concrete plates were obtained, which were then further processed by the MATLAB. In this paper, the T-SCAN hand-held laser scanner technical data were listed in the Table 3 and this commercial laser scanner, after verification by using a precision sphere $(\Phi=50 \mathrm{~mm})$ at $2.5 \mathrm{~m}, 4.0 \mathrm{~m}$, and $5.5 \mathrm{~m}$ distance, exhibited a maximum deviation of $40 \mu \mathrm{m}$. The linear Gaussian filter is fairly fashionable in surface characterization; it has been widely applied among researchers and it has become an industrial filtration standard characterized in the ISO standard [76]. The filter used in this paper is filtered by the software that comes with the laser scanner, as described in the reference [77].

Table 3. Technical data of T-SCAN hand-held laser scanner in this paper.

\begin{tabular}{cc}
\hline Measurement depth & $\pm 50 \mathrm{~mm}$ \\
\hline Line width & up to $125 \mathrm{~mm}$ \\
\hline Mean working distance & $150 \mathrm{~mm}$ \\
\hline Line frequency & up to $330 \mathrm{~Hz}$ \\
\hline Data acquisition rate & 210,000 points $/$ second \\
\hline Weight & $1100 \mathrm{~g}$ \\
\hline Sensor dimensions (incl. handle and IR pins) & $100 \times 170 \times 150 \mathrm{~mm}$ \\
\hline Cable length & $0.075 \mathrm{~mm}$ \\
\hline Mean point distance & Class $2 \mathrm{M}$ (eye-safe)
\end{tabular}




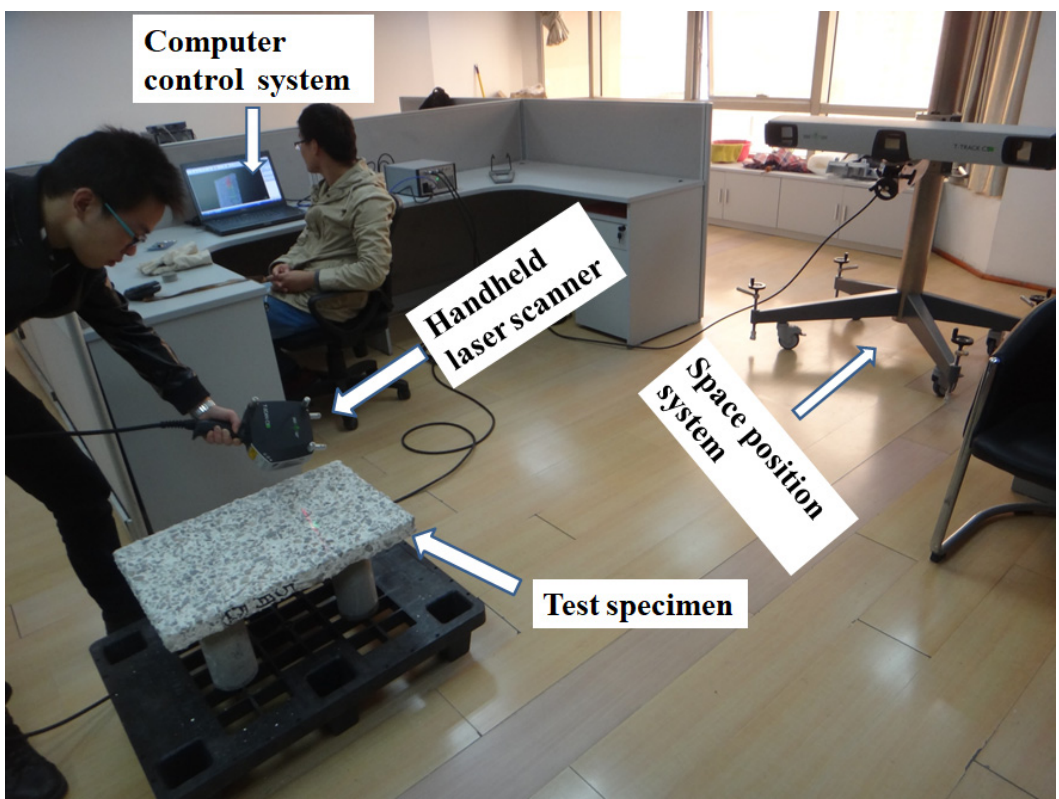

Figure 4. 3D laser scanning system produced by Steinbichler.

The fractal dimension of the corroded rough surface was calculated by a method called the cubic covering method, and this method was devised by Zhou and Xie [51]. The calculation principle of the cubic covering method calculating the fractal dimension of the rough surface of the corroded concrete slabs was as follows: a regular grid of squares with side length $\delta$ existed on the plane XOY, as shown in Figure 5. The four corners of the square grid ABCD correspond to four altitudes of the rough surface of corroded concrete plate: $h(i, j), h(i+1, j), h(i, j+1)$, and $h(i+1, j+1)$ (where $1 \leq i \leq \mathrm{n}-1,1 \leq j \leq \mathrm{m}-1, \mathrm{n}$ and $\mathrm{m}$ denoted the total sampling points of the rough surface along the $x$-axis directions and $y$-axis directions, respectively). If the rough surface was covered with a cube with side length $\delta$, the biggest deviation among $h(i, j), h(i+1, j), h(i, j+1)$, and $h(i+1, j+1)$ could determine the number $N_{i, j}(\delta)$ of cubes to cover the irregular surface within the scale $\delta$ :

$$
\begin{aligned}
N_{i, j}(\delta)=\quad & \operatorname{INT}\left\{\frac{1}{\delta}[\max (h(i, j), h(i, j+1), h(i+1, j), h(i+1, j+1))\right. \\
& -\min (h(i, j), h(i, j+1), h(i+1, j), h(i+1, j+1))]+1\}
\end{aligned}
$$

where INT represented the integral function. If the side length of the cube was $\delta$, the overall number of cubes covered the total irregular surface could be calculated as:

$$
N(\delta)=\sum_{i, j=1}^{n-1} N_{i, j}
$$

Change the cube side length $\delta$ to cover again, and then count the entire number of cubes $N(\delta)$ to cover the entire rough surface. It is obvious that the smaller $\delta$ is, the bigger $N(\delta)$ is.

If the irregular surface exhibited fractal characteristics, based on the fractal theory, there should be the following relationship between the overall amount of cubes $N(\delta)$ and the side length of the cube $\delta$.

$$
N(\delta) \sim \delta^{-D}
$$

where $D$ denotes the fractal dimension of the concrete irregular surface. 


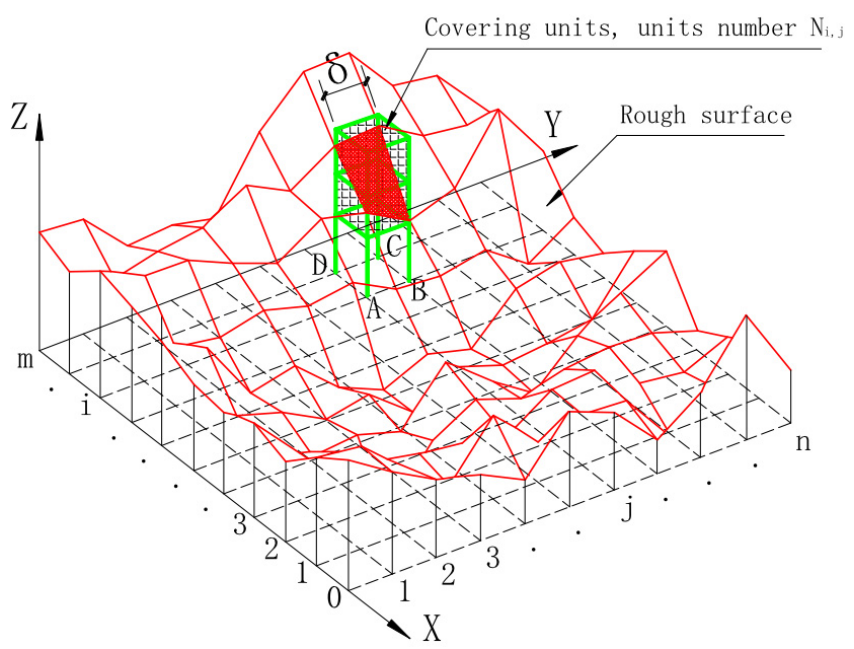

Figure 5. Schematic diagram of cubic covering method.

\subsection{Direct Shear Experiment for Interface between Sand and Corroded Concrete Plate}

The concrete plate was filled into the shear box at the bottom which could move horizontally, and the sand was filled into the upper shear box, which was fixed during the shearing. The vertical force of the direct shear device was used to simulate the soil pressure around the pile and the horizontal displacement of the direct shear device was used to simulate the vertical downward displacement of the pile, as shown in Figure 6. In order to cut down the mass of the concrete plate and make it convenient for manual handling, the concrete sample was designed to be $50 \mathrm{~mm}$ thick, rather than $100 \mathrm{~mm}$, which was the height of the shear box at the bottom. The concrete plate was adjusted by installing a steel plate of about $50 \mathrm{~mm}$ underneath to guarantee that the surface of the concrete specimen was at the same level as the upper surface of the shear box at the bottom. The reason the concrete slab was placed in this way was that when the concrete pile was corroded, the rough morphology of the concrete pile surface was somewhat similar to a sawtooth shape, as illustrated in Figure 6a. As is known to all, the shear strength of concrete material was bigger than that of sand. The shear strength of plane 2-2 in Figure 6a would be greater than that of plane 1-1. Therefore, the 1-1 plane was chosen as the shear interface and the concrete sample arrangement in the test is illustrated in Figure $6 \mathrm{~b}$.

For the purpose of maintaining the stability of the soil sample, $30 \mathrm{~kg}$ sand was weighed each time, and then the sand was filled into the shear box at the top and manually compacted the sand to the target relative density. Two load cells were adopted to measure the tangential and normal forces at the interface. Four linear variable displacement transducers (LVDTs) were used to obtain the normal displacement and tangential displacement at the interface. Four normal loads of 50, 100, 150, and $200 \mathrm{kPa}$ were used to carry out the direct shear test for each concrete plate. An initial normal stress of $200 \mathrm{kPa}$ was applied on the sand through loading plate for $20 \mathrm{~min}$ in order to make the normal deformation stable. Then, shear force was gradually applied to the shear box at the bottom until the tangential displacement did not exceed $35 \mathrm{~mm}$ since the shear box wall was $40 \mathrm{~mm}$ thick. The shear displacement rate used in this paper is $2.0 \mathrm{~mm} / \mathrm{min}$. The readings of the LVDTs and load cells were monitored and recorded by a data acquisition system, which was connected to a computer. In addition, the direct shear test of the sand itself was also carried out according to the above shear experimental procedure, but there were some differences: instead of concrete plate, $30 \mathrm{~kg}$ of sand was placed into the shear box at the bottom and the sand was manually compacted to the target relative density. 


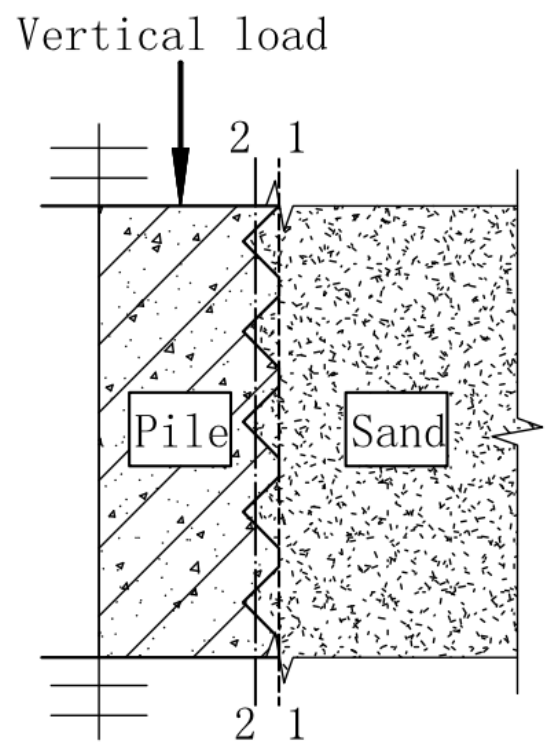

(a)

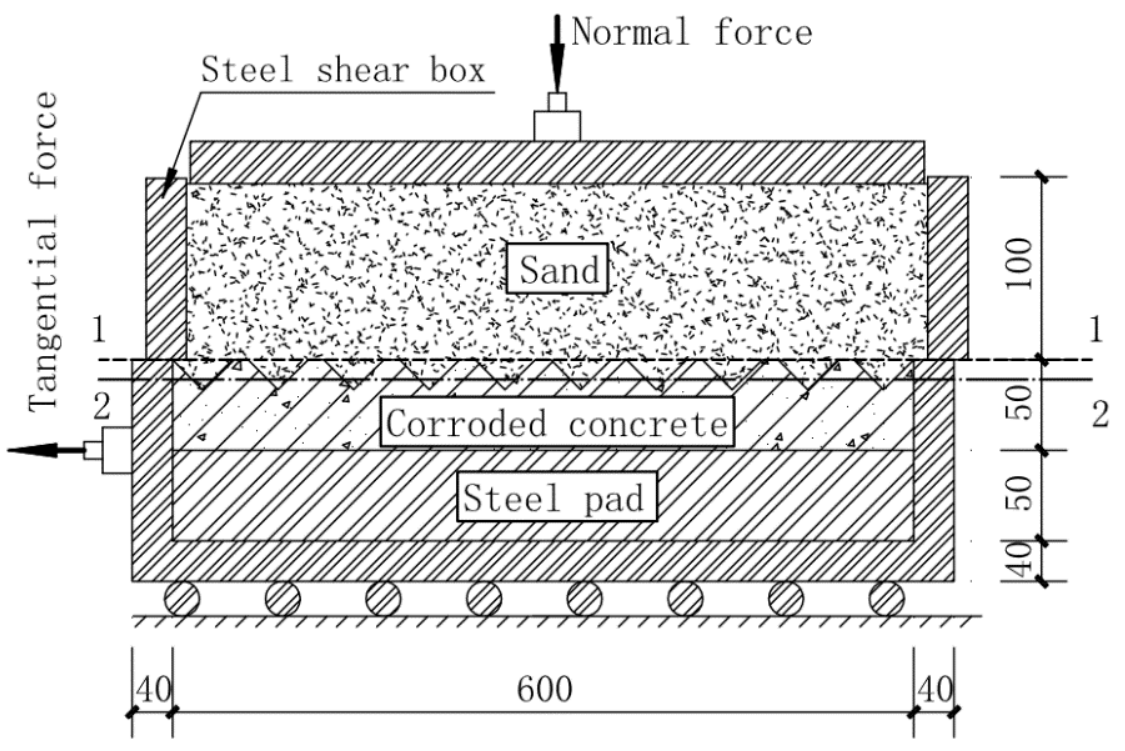

(b)

Figure 6. Schematic diagram of interface location selection of the interface between sand and corroded concrete. (a) Corroded pile and soil; (b) Soil and concrete specimen placed in the shear box.

\section{Experiment Results and Analysis}

\subsection{Appearance}

Photos of concrete plates soaked in the sulfuric acid for four predetermined durations ( 0 days, 31 days, 93 days, and 154 days) are shown in Figure 7. The degree of corrosion is obviously exhibited in the photos: the uncorroded surface after demolding was smooth and flat. After soaking for 31 days, the sulfuric acid reacted chemically with the alkaline substances in the concrete, resulting in the dissolution of the cement, the exposure of the sand, and the deposition of the white corrosion product, which was reported to be mainly gypsum. From the 31-day immersion to the 154-day immersion, the dissolution of the cement paste continued, the fine aggregates were gradually detached, and the coarse aggregates were gradually exposed.

\subsection{The Fractal Dimension Calculated Results}

The steps to obtain the fractal dimension of concrete plate surface under the sulfuric acid environment were the same as in reference [74], from which the detailed procedures could be obtained. The steps to obtain the fractal dimension were briefly described as follows. As shown in Figure 8, there were four steps. Step (1) and Step (2): obtain the three-dimensional coordinates of every point on the uncorroded and corroded concrete surface with a hand-held 3D laser scanning device called T-SCAN CS from Steinbichler). Step (3): In MATLAB software, extract the surface of the concrete plate corroded by sulfuric acid, and the points on the remaining surface of the concrete plate were removed. Step (4): Display the surface corroded by sulfuric acid in MATLAB software and adopt the cubic covering method, which was indicated in Section 2.4, to calculate the uncorroded and corroded surface fractal dimension. 


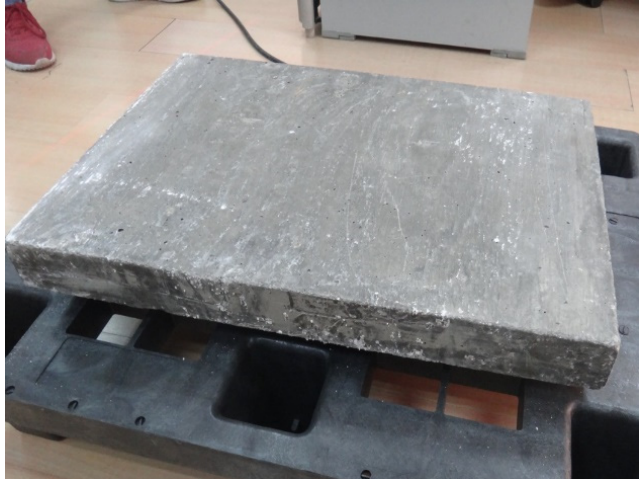

(a)

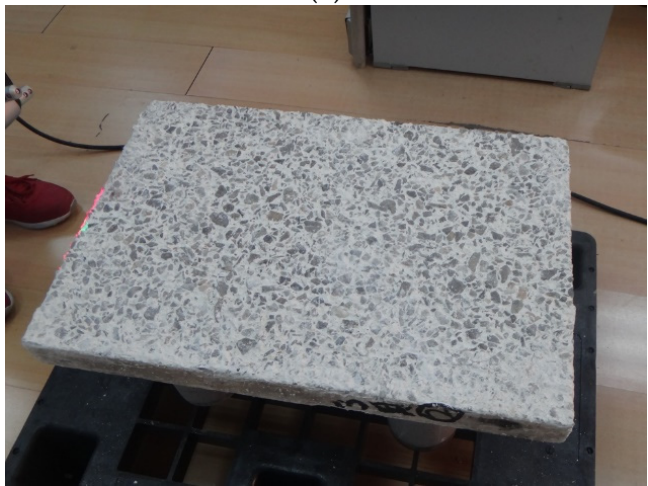

(c)

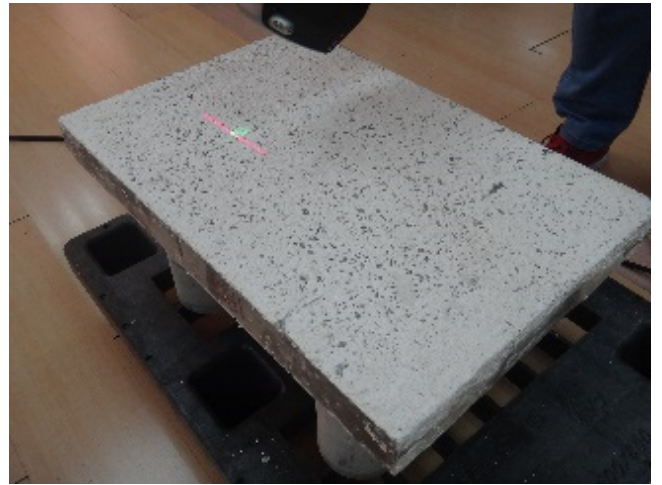

(b)

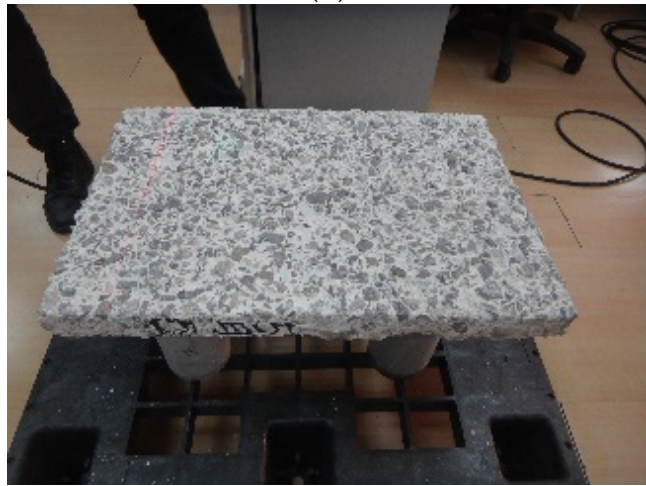

(d)

Figure 7. Photos of concrete plates eroded for 0,31, 93, and 154 days. (a) Concrete plate eroded for 0 days (uncorroded); (b) Concrete plate eroded for 31 days; (c) Concrete plate eroded for 93 days; (d) Concrete plate eroded for 154 days.

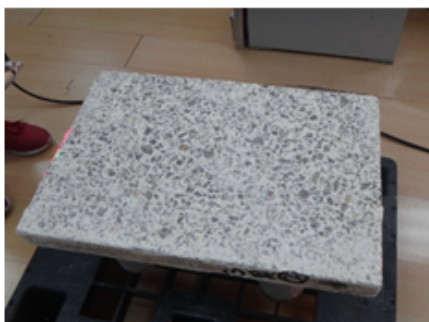

Step (1) Photograph of corroded concrete plate
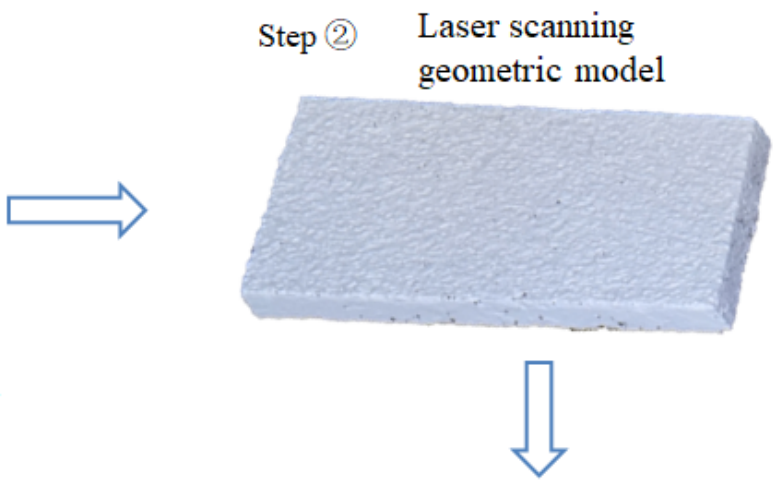
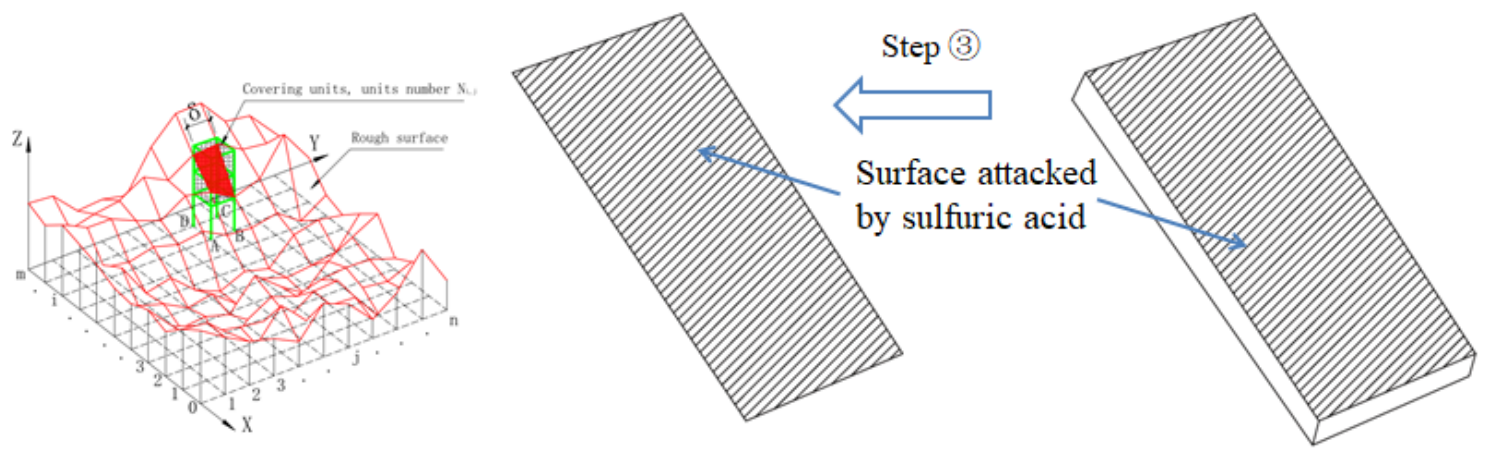

Step (4)

Fractal dimension calculation

Figure 8. Four steps to obtain the fractal dimension of concrete plates. 
In MATLAB software, the uncorroded and corroded surface of the concrete plates were illustrated in Figure 9. Nine different grid numbers were chosen for the four concrete specimens to generate nine kinds of different side lengths cubes: $75 \times 50,150 \times 100$, $300 \times 200,600 \times 400,900 \times 600,1200 \times 800,1500 \times 1000,2100 \times 1400$, and $3000 \times 2000$. Then, in these nine cases, the number of the square boxes $N(\delta)$ required to completely cover the surface by cubes with side length $\delta$ were obtained. The fractal dimension could be calculated from the relationship between $N(\delta)$ and $\delta$ as the above-mentioned Equation (3). Usually, the value of fractal dimension can be estimated from the slope of dual logarithmic coordinate graphs of $\ln (N(\delta))$ against $\ln (\delta)$, as shown in Figure 10. After calculation, the fractal dimensions of concrete specimens corroded for 0 days, 31 days, 93 days, and 154 days were $2.0094,2.034,2.078$, and 2.135, respectively. The fractal dimension of the concrete plate surface uncorroded is almost 2.00, indicating that the surface of the concrete plate after demolding was nearly a smooth plane. With the prolongation of corrosion time, the cement slurry was dissolved, and the exposure of the aggregates made the surface rougher and the fractal dimension greater, which indicated that the fractal dimension could characterize the growth law of surface roughness with corrosion time.

(a)
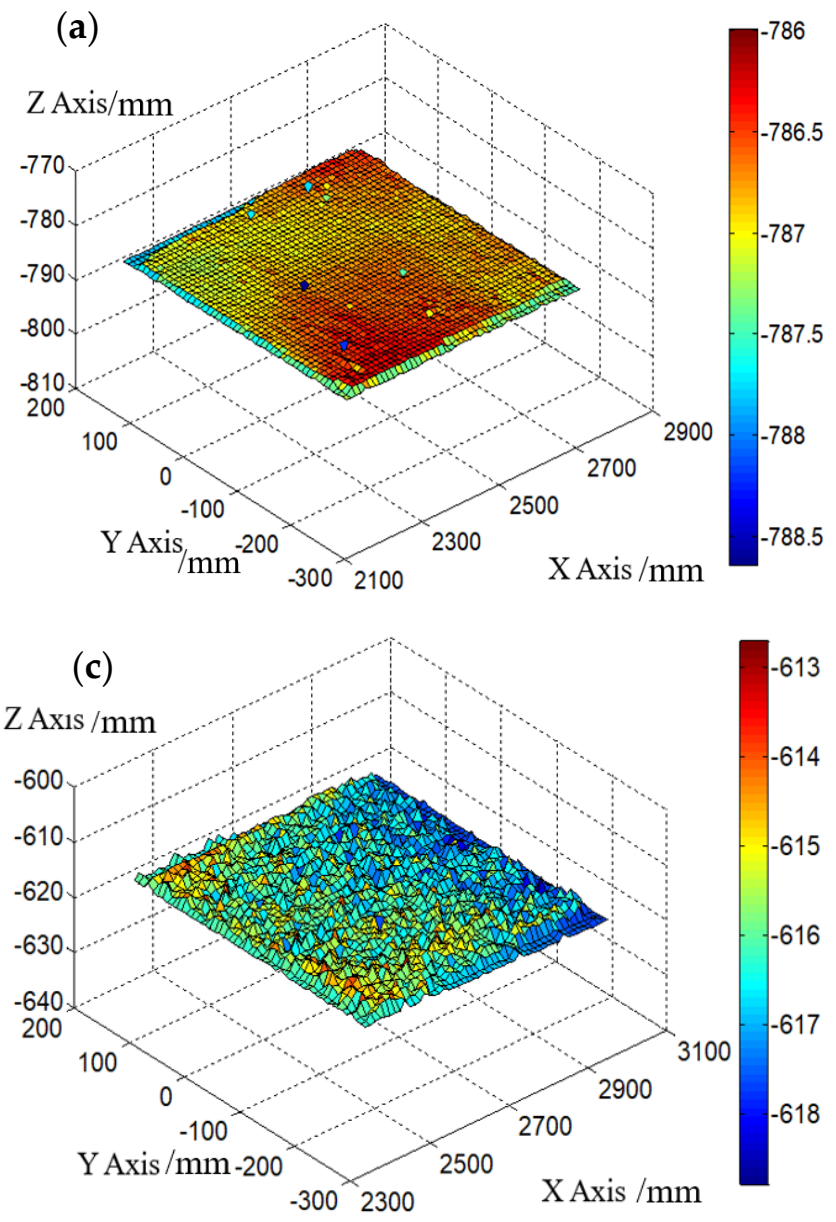

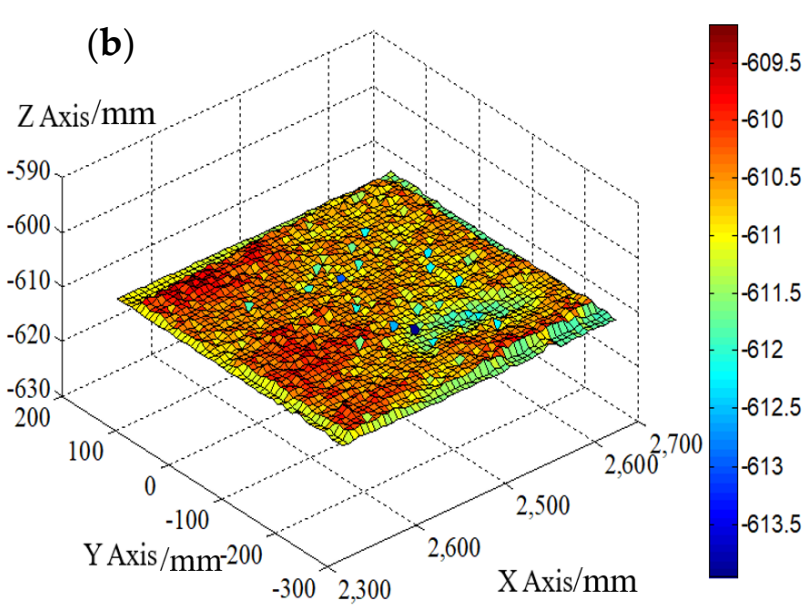

(d)

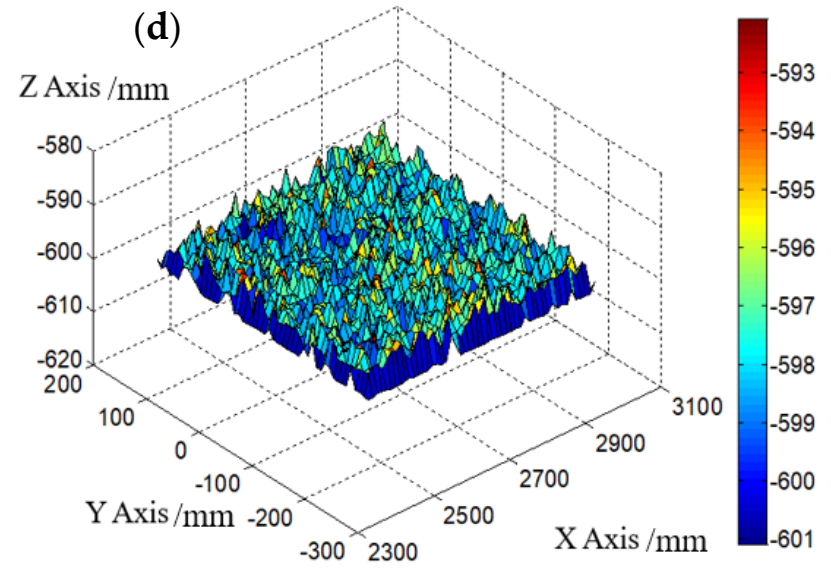

Figure 9. Reconstruction of the concrete plate surfaces corroded for 0, 31, 93, and 154 days in Matlab. (a) Concrete plate uneroded; (b) Concrete plate eroded for 31 days; (c) Concrete plate eroded for 93 days; (d) Concrete plate eroded for 154 days. 
(a)

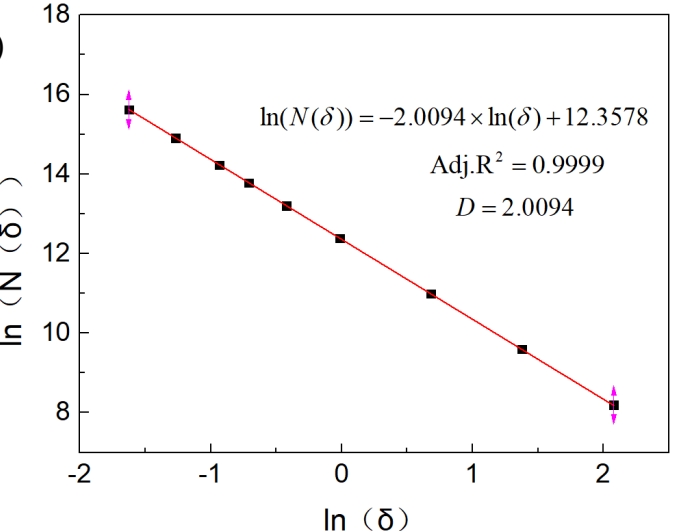

(c)

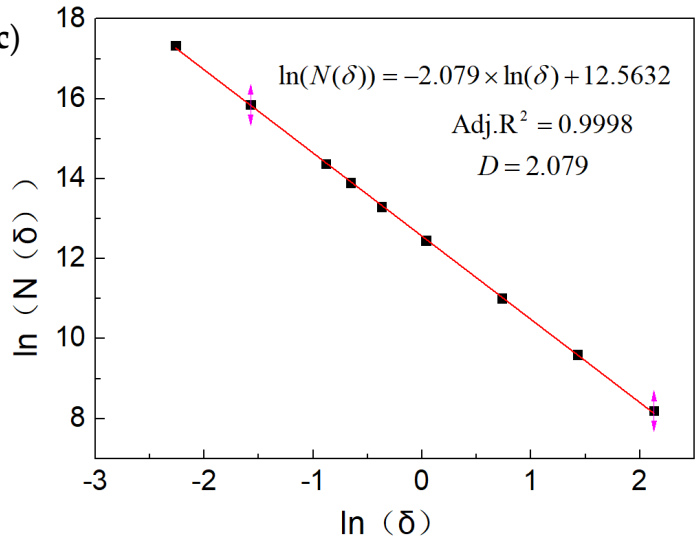

(b)

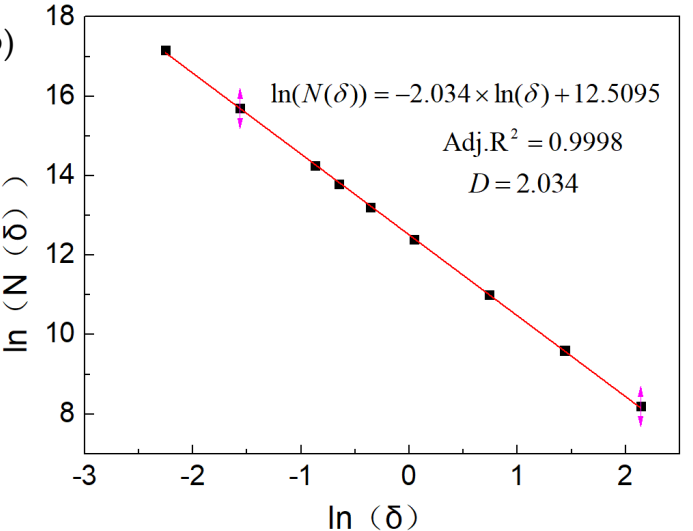

(d)

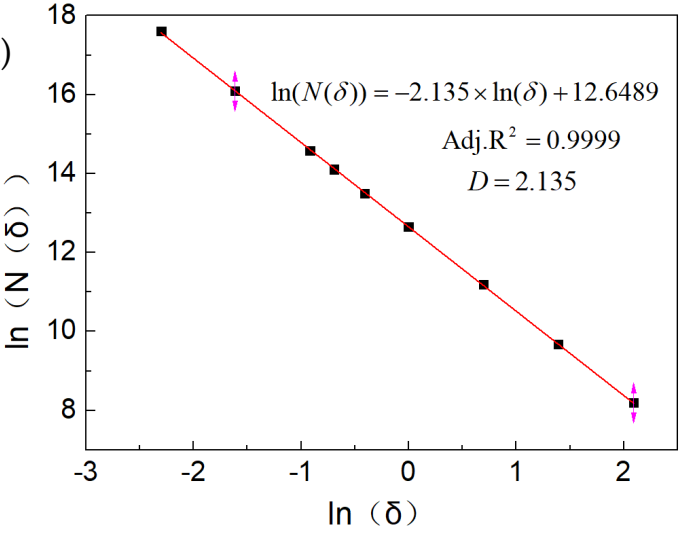

Figure 10. Dual logarithmic coordinate graphs of concrete specimens corroded for 0 days, 31 days, 93 days, and 154 days to calculate fractal dimensions. (a) Concrete uncorroded $(D=2.0094)$; (b) Concrete corroded for 31 days $(D=2.034)$; (c) Concrete corroded for 93 days $(D=2.079)$; (d) Concrete corroded for 154 days $(D=2.135)$.

\subsection{Direct Shear Experimental Results of the Interface}

The shear stress-shear displacement curves of the interface between concrete plates eroded for 0 days, 31 days, 93 days, and 154 days and sand were presented in Figure 11a-d. The curves had some common characteristics. In the initial stage, the shear stress was substantially proportional to the shear displacement. In this stage, the interface shear modulus was constant and relatively large. As the shear displacement increased, the increase rate of shear stress gradually decreased, and finally, with the growth of shear displacement, the shear stress was almost constant, which indicated the interface yield. Since there is no evident peak value in the relation curve of the interface shear stress and shear displacement between four concrete plates and sand, it made sense to take the interface yield stress as the shear strength. The shear displacement and shear stress exhibit an elastic-plastic relationship and could be expressed in terms of a hyperbolic model. The test results of the direct shear experiment of the interface between concrete specimens under sulfuric acid environment and sand for four different periods were listed in Table 4.

The test method for the interfacial relation curve of shear stress and shear displacement between sand and sand was similar to the previous test method for the interfacial relation curve of shear stress and shear displacement between concrete plate and sand, except that when measuring the relation curve of shear stress and shear displacement of sand itself, the shear box at the bottom was filled by sand instead of the concrete plate. The interfacial shear stress-displacement curve between sand and sand was shown in Figure 12. The results of the direct shear experiments for the sand itself were listed in Table 4. 


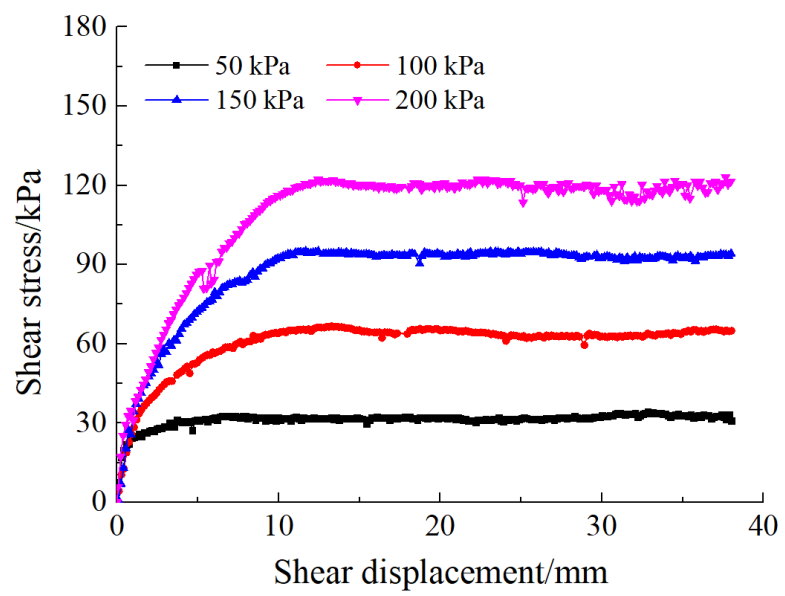

(a)

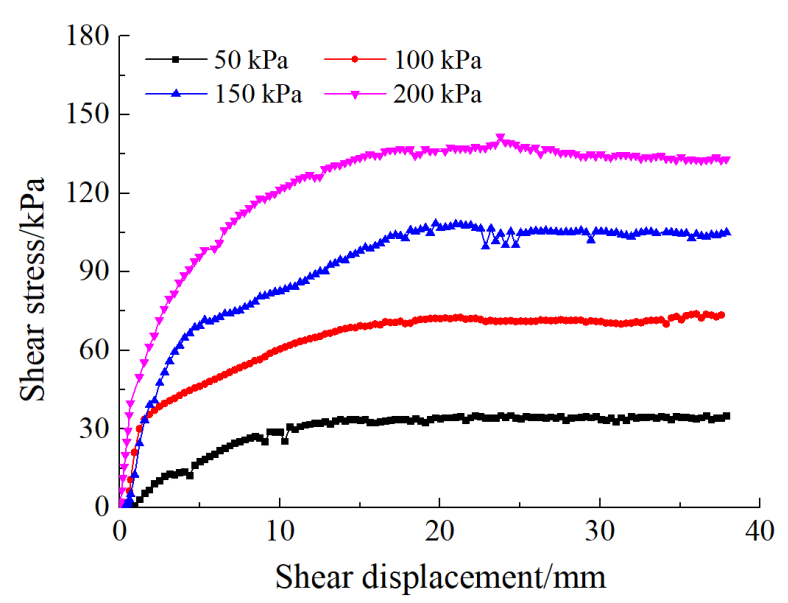

(c)

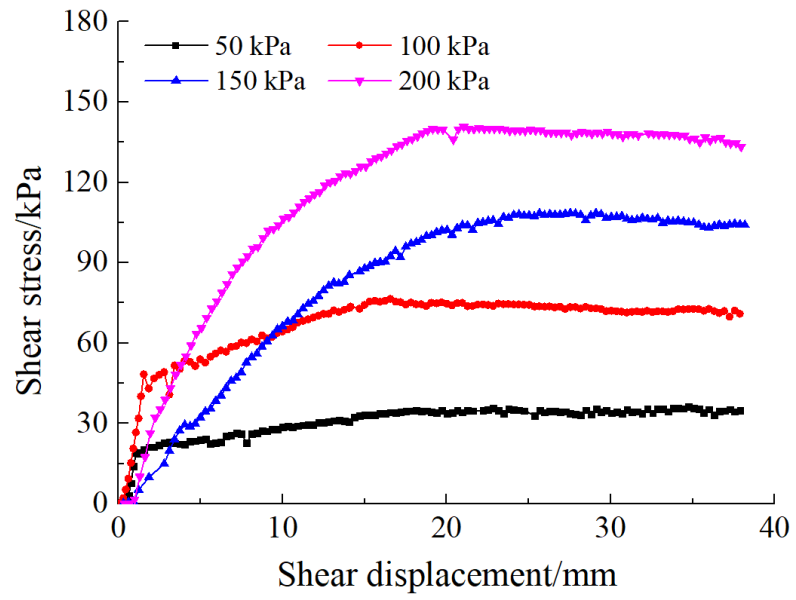

(b)

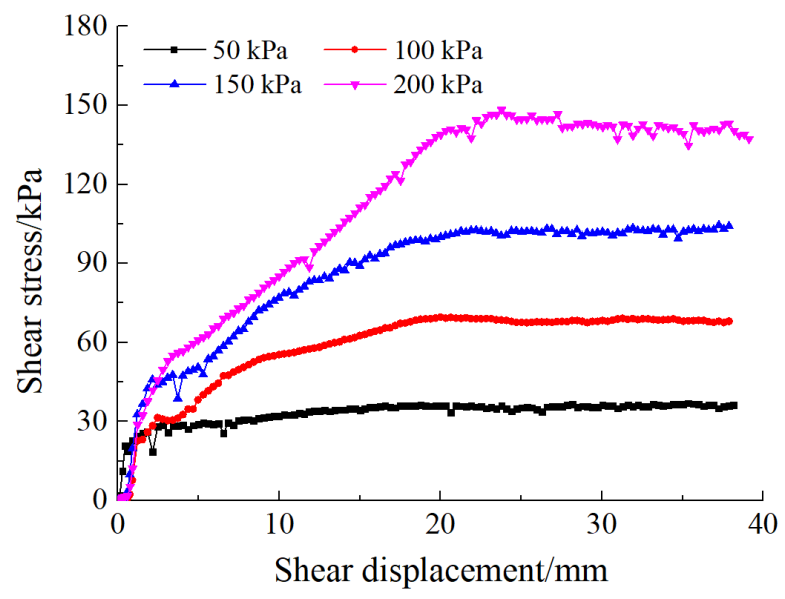

(d)

Figure 11. The relation curve of interface shear stress and shear displacement between sand and concrete specimens corroded different periods. (a) Concrete plate eroded for 0 days (uncorroded); (b) Concrete plate eroded for 31 days; (c) Concrete plate eroded for 93 days; (d) Concrete plate eroded for 154 days.

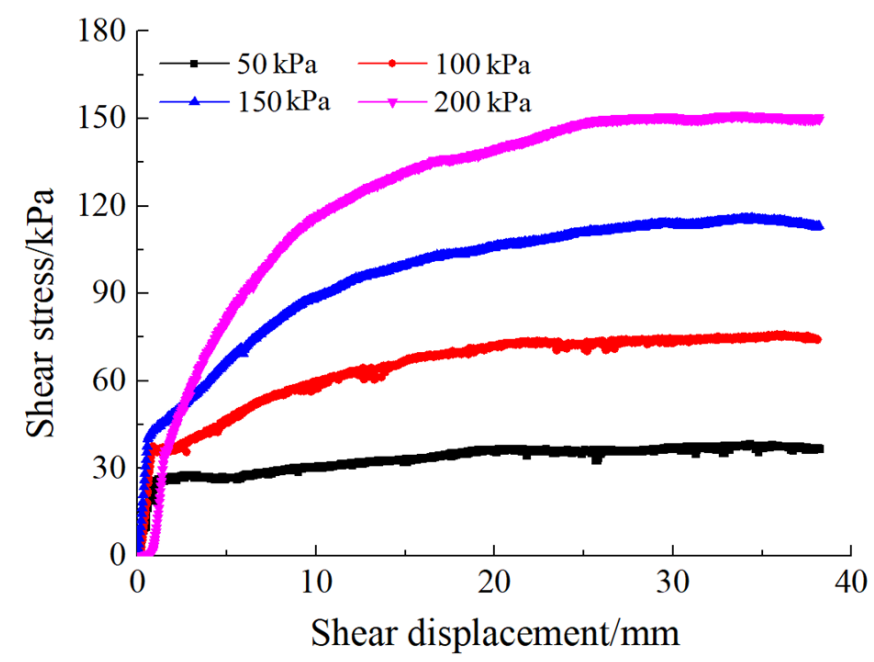

Figure 12. The relation curve of the interface shear stress and shear displacement of sand itself. 
Table 4. Direct interface shear experimental results and fitted parameters of the experimental data.

\begin{tabular}{|c|c|c|c|c|c|c|c|c|c|c|}
\hline \multirow[b]{2}{*}{ Test Plan } & \multirow[b]{2}{*}{$\begin{array}{l}\text { Corrosion } \\
\text { Time/Days }\end{array}$} & \multirow[b]{2}{*}{$\begin{array}{l}\text { Normal } \\
\text { Stress } \\
\sigma / \mathbf{k P a}\end{array}$} & \multicolumn{5}{|c|}{ Direct Interface Shear Experimental Results } & \multicolumn{3}{|c|}{ Fitting Parameters } \\
\hline & & & $\begin{array}{c}\text { Peak } \\
\text { Stress } \\
\tau_{f} / \mathbf{k P a}\end{array}$ & $\begin{array}{c}\text { Displacement } \\
\text { at Peak Stress } \\
\quad \omega_{f} / \mathrm{mm}\end{array}$ & $\begin{array}{l}\text { Cohesive } \\
c / \mathbf{k P a}\end{array}$ & $\begin{array}{c}\text { Friction } \\
\text { Angle } \varphi /^{\circ}\end{array}$ & $\operatorname{Adj.} R^{2}$ & $a$ & $b$ & $\operatorname{Adj.} R^{2}$ \\
\hline \multirow{16}{*}{$\begin{array}{l}\text { Direct shear } \\
\text { test for sand } \\
\text { and concrete } \\
\text { specimens } \\
\text { immersed in } \\
\text { sulfuric acid } \\
\text { for different } \\
\text { days }\end{array}$} & \multirow{4}{*}{0} & 50 & 32.79 & 6.57 & \multirow{4}{*}{3.39} & \multirow{4}{*}{30.87} & \multirow{4}{*}{0.996} & 0.0197 & 0.0303 & 0.997 \\
\hline & & 100 & 66.88 & 13.25 & & & & 0.0170 & 0.0149 & 0.996 \\
\hline & & 150 & 96.15 & 11.97 & & & & 0.0126 & 0.0103 & 0.997 \\
\hline & & 200 & 122.58 & 12.82 & & & & 0.0121 & 0.0080 & 0.994 \\
\hline & \multirow{4}{*}{31} & 50 & 35.33 & 8.79 & \multirow{4}{*}{4.09} & \multirow{4}{*}{34.65} & \multirow{4}{*}{0.995} & 0.0622 & 0.0269 & 0.936 \\
\hline & & 100 & 82.07 & 20.05 & & & & 0.0252 & 0.0126 & 0.957 \\
\hline & & 150 & 110.16 & 18.63 & & & & 0.0845 & 0.0065 & 0.952 \\
\hline & & 200 & 147.10 & 18.78 & & & & 0.0399 & 0.0057 & 0.955 \\
\hline & \multirow{4}{*}{93} & 50 & 37.28 & 15.30 & \multirow{4}{*}{1.43} & \multirow{4}{*}{35.27} & \multirow{4}{*}{0.999} & 0.1337 & 0.0237 & 0.962 \\
\hline & & 100 & 75.36 & 16.78 & & & & 0.0399 & 0.0124 & 0.980 \\
\hline & & 150 & 110.25 & 18.30 & & & & 0.0338 & 0.0083 & 0.980 \\
\hline & & 200 & 149.61 & 19.17 & & & & 0.0162 & 0.0067 & 0.986 \\
\hline & \multirow{4}{*}{154} & 50 & 35.34 & 16.90 & \multirow{4}{*}{0.243} & \multirow{4}{*}{36.44} & \multirow{4}{*}{0.991} & 0.0230 & 0.0276 & 0.909 \\
\hline & & 100 & 76.58 & 21.88 & & & & 0.0580 & 0.0124 & 0.978 \\
\hline & & 150 & 107.97 & 22.98 & & & & 0.0478 & 0.0081 & 0.975 \\
\hline & & 200 & 150.46 & 34.54 & & & & 0.0544 & 0.0052 & 0.964 \\
\hline \multirow{4}{*}{\multicolumn{2}{|c|}{$\begin{array}{l}\text { Direct shear test for the } \\
\text { sand itself }\end{array}$}} & 50 & 36.98 & 20.04 & \multirow{4}{*}{0.055} & \multirow{4}{*}{37.61} & \multirow{4}{*}{0.998} & 0.0626 & 0.0250 & 0.996 \\
\hline & & 100 & 73.77 & 22.20 & & & & 0.0438 & 0.0121 & 0.998 \\
\hline & & 150 & 115.87 & 34.03 & & & & 0.0349 & 0.0077 & 0.999 \\
\hline & & 200 & 151.36 & 33.48 & & & & 0.0231 & 0.0059 & 0.997 \\
\hline
\end{tabular}

Figure 13 shows the shear strengths of the interfaces between sand and concrete plates soaked in the sulfuric acid solution for four different days under different normal stresses and the shear strength of sand itself under different normal stresses. These curves represented that the shear strength increased linearly with the increase of the normal stress, which demonstrated that the shear performance of the interfaces between corroded concrete and sand complied with the Mohr-Coulomb law, as illustrated in Equation (4). The test data in Figure 12 were plotted in the coordinate diagram, where the abscissa was the normal stress and the ordinate was the shear strength of the interface. The least-square method was employed to fit the data points to obtain the shear strength parameters (i.e., friction angle and the cohesive), which were presented in Table 4.

$$
\tau_{f}=\sigma \tan \varphi+c
$$

where $\tau_{f}$ denotes the maximum shear stress (shear strength), $\mathrm{kPa} ; \sigma$ denotes the normal stress, $\mathrm{kPa} ; \varphi$ denotes the friction angle; and $c$ denotes the cohesive force, $\mathrm{kPa}$.

As shown in Figure 13, as the immersion days increased, the friction angle of the sand and corroded concrete interface gradually increased.The friction angle of the interface between corroded concrete and sand was larger than that of the interface between uncorroded concrete and sand, but smaller than that of sand itself. This meant that the shearing resistance of corroded rougher interfaces was still weaker than that of the sand itself, but was stronger than that of the uncorroded smooth interface. 


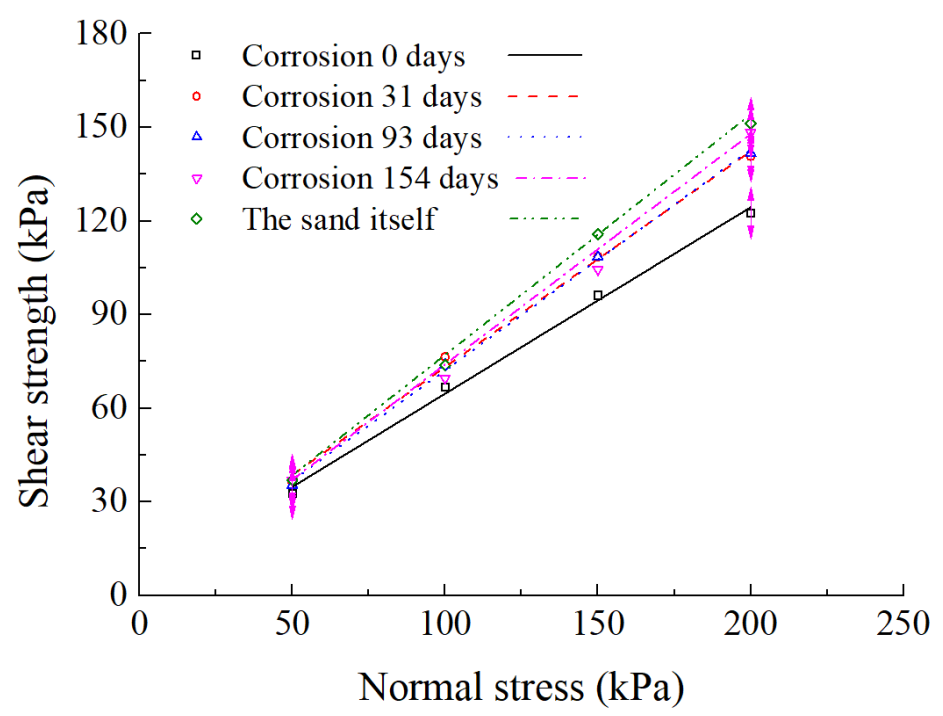

Figure 13. The shear strengths of sand-corroded concrete interfaces and sand itself for different days under different normal stresses.

It was an important aspect of the study of the mechanical behavior of the interface to establish the constitutive model of the interface between soil and structure. The constitutive relation of the interface referred to the relationship between the normal and tangential components of the interaction force or stress at the interface and the normal and tangential components of the relative displacement at the interface. At present, the constitutive relation of the interface generally referred to the relationship between shear stress and relative shear displacement. There were many constitutive models of the interface between structure and soil to simulate the property of the interface between structure and soil, such as the Clough-Duncan hyperbolic model, the elastic-plastic model [78], and the rigid plastic model [79]. Among these models, the hyperbolic constitutive model, which was proposed by Duncan and Clough, was widely applied because the formula was simple, and the parameters were easy to determine, and the physical implications of the parameters were clear. The relationship between the shear stress and the shear displacement of the interface in the Clough-Duncan hyperbolic constitutive model was shown as follows:

$$
\tau=\frac{\omega}{a+b \omega}
$$

where $\tau$ denotes interface shear stress, $\omega$ represents the shear displacement between corroded concrete and sand, and $a$ and $b$ denote parameters obtained by fitting the test data of the shear stress and shear displacement. When the interfacial shear displacement $\omega$ tends to infinity, the interfacial shear stress tends to a constant $\tau_{f}$, which is named ultimate shear stress. As the interfacial shear displacement $\omega$ tends to zero, the initial shear stiffness is defined as the value of shear stress divided by shear displacement, denoted by the symbol $k_{s 0}$. Therefore, the physical implication of fitted parameter $a$ in Equation (6) was the reciprocal of the initial shear stiffness, while the physical implication of fitted parameter $b$ was equal to the reciprocal of the value of ultimate shear stress. Parameters $a$ and $b$ in the Clough-Duncan hyperbolic constitutive model were obtained by fitting the test data of the shear displacement and shear stress between sand and corroded concrete plate for four different periods of time. The results of the fitting parameters $b$ and $a$ were presented in Table 4. For convenience, the test data of the shear stress and shear displacement between concrete plate corroded for 93 days and sand was employed as an example to show the comparison of the experimental data points and fitted curves of shear displacement and 
shear stress, as illustrated in Figure 14. The comparison result indicated that the test data points were in good agreement with the fitted curve.

$$
\left\{\begin{array}{l}
\lim _{\omega \rightarrow \infty} \tau=\lim _{\omega \rightarrow \infty} \frac{\omega}{a+b \omega}=\frac{1}{b}=\tau_{f} \\
\lim _{\omega \rightarrow 0} \frac{\tau}{\omega}=\lim _{\omega \rightarrow 0} \frac{1}{a+b \omega}=\frac{1}{a}=k_{s 0}
\end{array}\right.
$$

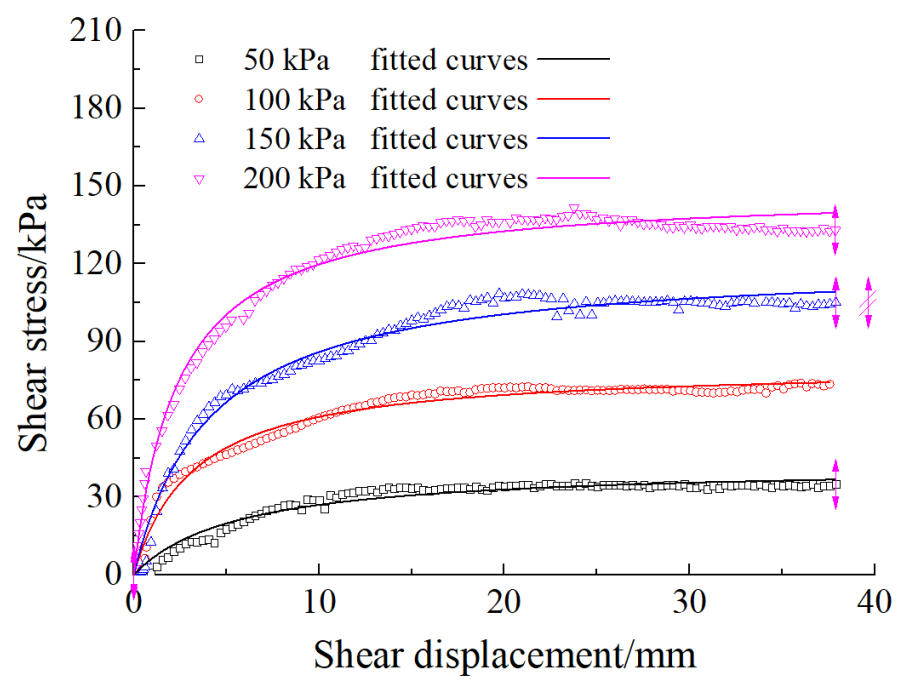

Figure 14. The comparison of the tested data points and fitted curves of shear stress and shear displacement between concrete plate corroded for 93 days and sand.

\subsection{Correlation between Interface Shear Strength and Fractal Dimension}

The friction angle between concrete and sand played an important role in the shear strength at the interface. Therefore, we aimed to explore the effect of the roughness of the concrete surface on the interface shear strength between corroded concrete and sand by finding the relation between the friction angle and the fractal dimension of the concrete surface. In the initial stage, the friction angle increased rapidly as the fractal dimension increased, but at the later stage, the growth rate of the friction angle decreased with the increase of the fractal dimension and tended to become steady, as illustrated in Figure 15 and Equation (7). The results showed that the test data points were in good agreement with the fitted curve.

$$
\varphi=38.26 \times(D-2.0094)^{0.0161}
$$

where $\varphi$ represented the interface friction angle of the interface and $D$ denoted the fractal dimension of the rough surface of the corroded concrete. In this initial stage, the reason the friction angle increased rapidly as the fractal dimension increased is that with the dissolution of cement paste, white corrosion products were deposited on the surface of concrete plate, and the gradual exposure of coarse aggregate and fine aggregate caused the surface of the concrete to become rough from the initial smooth surface. However, in the next erosion stages, on the one hand, corrosion products and fine aggregate gradually fell off, which would reduce the surface roughness of the concrete slab. On the other hand, due to the further dissolved cement paste, the newly exposed aggregate could increase the surface roughness. Under the combined influence of these two effects, the surface roughness of the concrete plate became stable, as shown in Figure 16. 


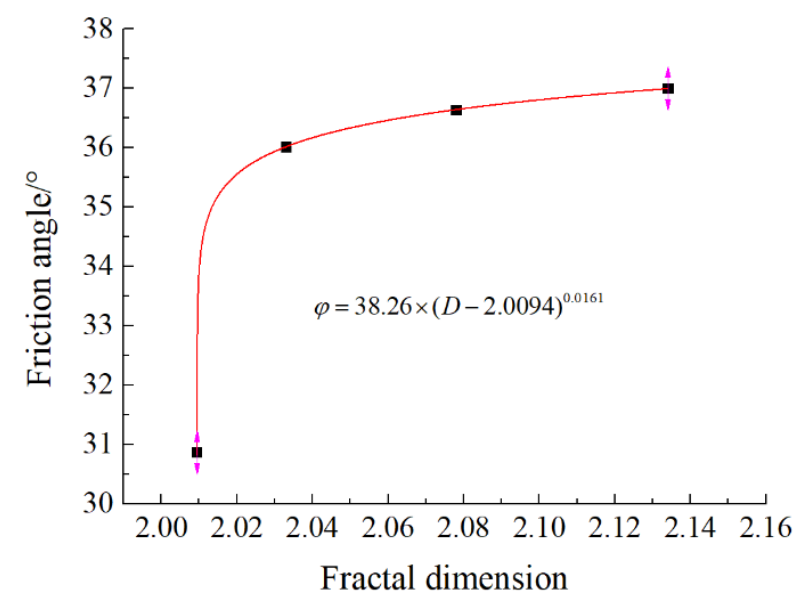

Figure 15. Curves of fractal dimension and interface friction angle.

(a)

$$
\text { Corrosion surface Initial surface }
$$
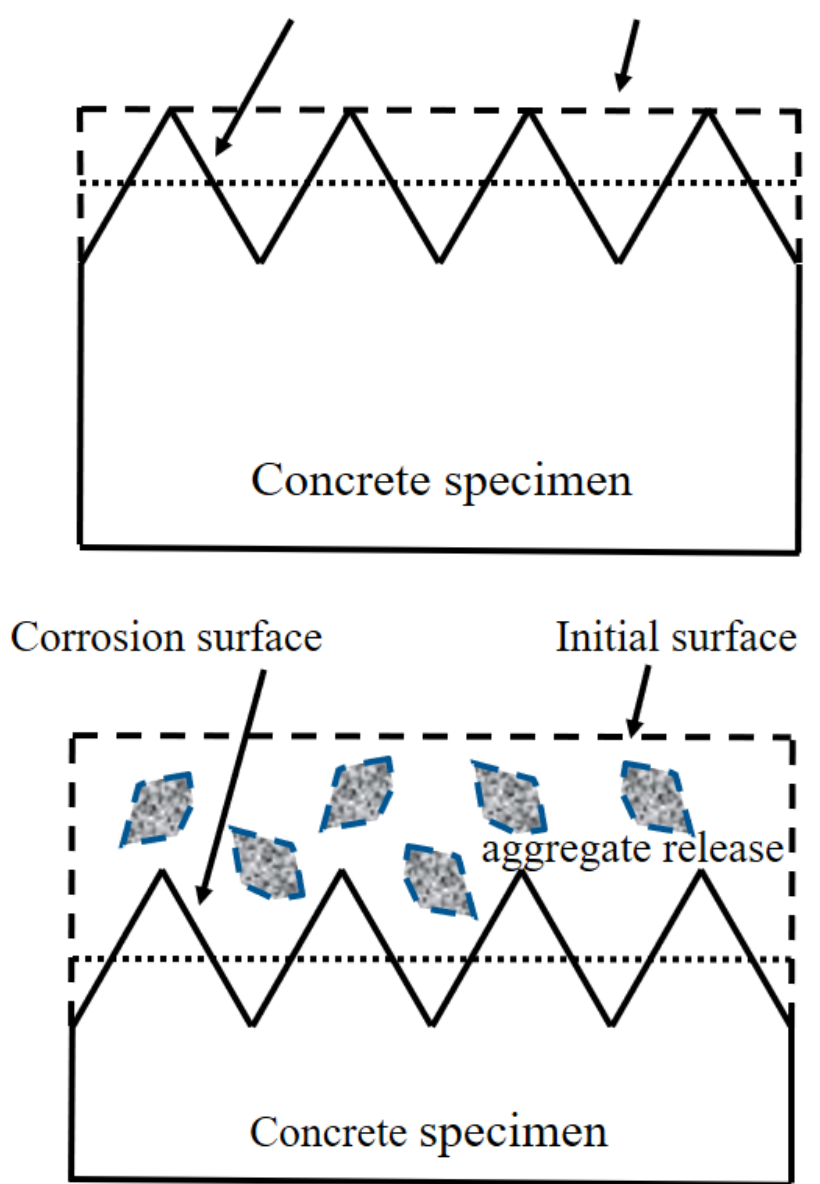

Figure 16. Analysis of the reasons of the roughness changes of the surface at different stages. (a) At the early erosion stages, (b) At the later erosion stages.

\subsection{Influence of Fine Marble Aggregate on Interface Properties}

For the purpose of investigating the effect of fine marble aggregate on the interface shear strength and surface fractal dimension when the concrete specimen was under the sulfuric acid environment, the friction angle of the interface and the surface fractal dimension of the concrete in this paper were compared with those in the reference [74], as illustrated in Table 5 and Figure 17. 
Table 5. Comparison of the friction angle of the interface and fractal dimension between this paper and reference.

\begin{tabular}{cccc}
\hline & Corrosion Time/Days & In This Paper & In the Reference [74] \\
\hline Coarse aggregate & & Crushed gravel & Crushed gravel \\
Fine aggregate & 0 & Marble sand & River sand \\
& 31 & 30.87 & 30.87 \\
Interface friction angle ${ }^{\circ}$ & 93 & 36.02 & 34.65 \\
& 154 & 36.64 & 35.27 \\
& 0 & 37.00 & 36.44 \\
Surface fractal dimension & 31 & 2.0094 & 2.0094 \\
& 93 days & 2.1269 & 2.033 \\
& 154 days & 2.1827 & 2.078 \\
& & 2.192 & 2.134 \\
\hline
\end{tabular}
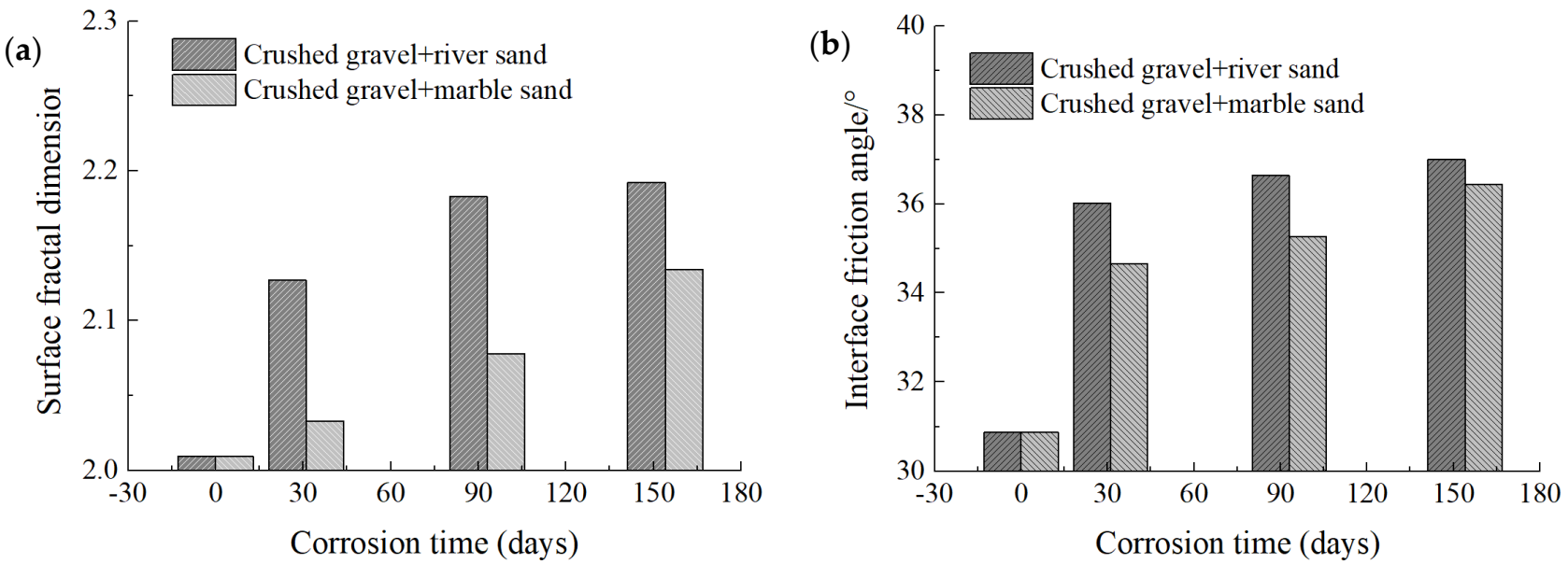

Figure 17. Comparison of the friction angle of the interface and fractal dimension between this paper and reference. (a) surface fractal dimension, (b) interface friction angle.

From Table 5 and Figure 17, we find that the friction angle of the interface and the surface fractal dimension of the concrete plate containing crushed gravel and marble sand were smaller than that of the concrete plate containing crushed gravel and river sand. This was attributed to the different fine aggregate. If concrete specimens contained siliceous aggregates (river sand), only the hydration products of the cement reacted with sulfuric acid and the neutralization ability in the process of acid attack could be very limited while crushed marble sand generally contains calcium carbonate, which easily reacts with acid and the concrete specimens would have greater neutralization ability to react with acid and the rate of the acid attack on specimens would be reduced. Therefore, concrete plate with marble sand as fine aggregate in this paper produced a smaller surface fractal dimension and formed a smoother surface. The smoother surface led to a smaller interface friction angle.

\section{Discussion}

Previous studies have found that concrete specimens containing marble sand have better performance in terms of mass loss and corrosion depth than concrete specimens containing river sand. When concrete is used in a pile foundation, in addition to mass loss, corrosion depth, and so on, the effect of acid corrosion on the mechanical properties of pile-soil interface is also of concern for researchers and engineers. In order to study the effect of acid corrosion on the mechanical properties of the pile-soil interface, three issues need to be considered: how to produce rough surfaces, how to measure rough surfaces, and how to calculate roughness evaluation parameters. Firstly, most of the researchers adopted regular, artificial rough surfaces to simulate the interfacial roughness of actual piles. In this 
paper, the rough surfaces of concrete slabs were generated by completely soaking for 0 , 31,93 , or 154 days (the actual soaking periods) in sulfuric acid solution with $\mathrm{pH} \approx 0.95$. Secondly, different from the traditional comparison method, mechanical stylus method and sand patch test, in this paper, geometric models of the rough surface were captured using a 3D laser scanning technology, which had the obvious advantages of high measuring accuracy, good portability, automatic reconstruction of 3D shapes, non-destruction, and non-contact with the detected object. Thirdly, the fractal dimension was adopted to evaluate the surface roughness, which could be determined independently from the resolution and sampling range of the roughness measurement instrument. Due to its wide availability and relatively simple test setup and sample preparation procedures, direct shear apparatus was adopted for interface testing in this research. However, in order to better simulate the variation rule of concrete pile lateral friction in actual engineering acidic soil, a model box test or field test can be used to carry out research in the future.

In order to better represent the roughness of the concrete slab in this paper, the following calculation was carried out. As one of the 3D characterization parameters of surface roughness, areal surface roughness Sa is most commonly used to quantitatively describe surface topography. It is the arithmetic mean of the absolute values of the surface deviations from the mean plane as described in Equation (8) [80].

$$
\mathrm{Sa}=\frac{1}{\mathrm{~A}} \int_{0}^{\mathrm{x}} \int_{0}^{\mathrm{y}}|\mathrm{Z}(\mathrm{x}, \mathrm{y})| \mathrm{dxdy}
$$

where $\mathrm{A}$ is the sampling area, $\mathrm{x}, \mathrm{y},|\mathrm{Z}(\mathrm{x}, \mathrm{y})|$ are the values of a data point on the $x$-axis, $y$-axis, $z$-axis. Sa is the average surface roughness evaluated over the complete 3D surface. After calculation, the areal surface roughness Sa of concrete specimens corroded for 0 days, 31 days, 93 days, and 154 days were $0.2057,0.3236,0.627$, and 1.2731 , respectively.

\section{Conclusions}

(1) The surface of the concrete cast with crushed gravel and marble sand as aggregates exhibited fractal characteristics after being corroded by sulfuric acid. The surface fractal dimensions of the corroded concrete plate under sulfuric acid environment increased with the increase of the corrosion time.

(2) The shear strength of the interface increased linearly as the normal stress increased, and the relationship between the interface shear strength and the interface normal stress complied with the Mohr-Coulomb rule. The interface friction angle between sand and the corroded concrete plate was smaller than that of sand itself.

(3) As the corrosion days increased, the surface of the concrete plate became gradually rougher, and the friction angle of the interface became greater. In the initial stage, the friction angle increased rapidly with the increase of the fractal dimension from $30.87^{\circ}$ to $34.65^{\circ}$, but in the later stage, the growth rate of the friction angle decreased with the increase of the fractal dimension and tended to be stable from $34.65^{\circ}$ to $36.44^{\circ}$.

(4) The hyperbolic constitutive model proposed by Clough and Duncan was used to regress the relation between the shear stress and shear displacement of the corroded concrete-sand inteface. Parameters $\mathrm{a}$ and $\mathrm{b}$ in the hyperbolic constitutive model were achieved by fitting the test data.

(5) The friction angle of the interface and the surface fractal dimension of the concrete plate containing crushed gravel and marble sand were smaller that that of the concrete plate containing crushed gravel and river sand.

Author Contributions: J.X., H.J. and W.Q. mostly contributed to the design of the manuscript. Z.X., L.W. and Y.M. carried out data collection and processing. B.L. and L.C. were involved in immersing the specimens. L.W. and J.X. revised the paper. All authors have read and agreed to the published version of the manuscript. 
Funding: The authors appreciate the financial support provided by the National Natural Science Foundation of China with No. 51808133, the National Natural Science Foundation of China with Grant No. 51778150, and the National Natural Science Foundation of China with Grant No. 51678430

Institutional Review Board Statement: Studies not involving humans.

Informed Consent Statement: Studies not involving humans.

Data Availability Statement: The data that support the findings of this study are available from the corresponding author upon reasonable request.

Acknowledgments: The authors would like to thank the three anonymous referees for their constructive comments and suggestions.

Conflicts of Interest: The authors declare no conflict of interest.

\section{Nomenclature}

LVDTs

$\rho_{\max }$

$\rho_{\min }$

$e_{\max }$

$e_{\min }$

$C_{u}$

$\mathrm{C}_{c}$

$h(i, j), h(i+1, j), h(i, j+1)$

and $h(i+1, j+1)$ (where

$1 \leq i \leq \mathrm{n}-1,1 \leq j \leq \mathrm{m}-1)$

$\mathrm{n}$

$\mathrm{m}$

$N_{i, j}(\delta)$

$N(\delta)$

$D$

$\tau$

$\omega$

$a$ and $b$

$\tau_{f}$

$k_{s 0}$

$\varepsilon_{u}$

$a$ and $b$

$\omega_{f}$

$c$

$\varphi$

Sa linear variable different transformers

the maximum density of the sand

the minimum density of the sand

the maximum void ratio of the sand

the minimum void ratio of the sand

the coefficient of uniformity of the sand

the coefficient of curvature of the sand

the four corners of the square grid $\mathrm{ABCD}$ correspond to four altitudes of the rough sur-face of corroded concrete plate

the total sampling points of the rough surface along the $x$-axis directions the total sampling points of the rough surface along the $y$-axis directions when its side length is $\delta$, the number of cubes required to cover the rough surface in the $\mathrm{ABCD}$ grid area

when its side length is $\delta$, the number of cubes required to cover the total rough surface

the fractal dimension of the concrete irregular surface

the interface shear stress

the shear displacement between corroded concrete and sand

parameters obtained by fitting the test data of the shear stress and shear displacement

the ultimate shear stress

the initial shear stiffness

the ultimate strain

regression parameters in the constitutive relation proposed by Guo the displacement at peak stress

cohesive

friction angle

normal stress

the average surface roughness evaluated over the complete 3D surface

\section{References}

1. Yuan, B.X.; Li, Z.H.; Zhao, Z.Q.; Ni, H.; Su, Z.L.; Li, Z.J. Experimental study of displacement field of layered soils surrounding laterally loaded pile based on transparent soil. J. Soils Sediments 2021, 21, 3072-3083. [CrossRef]

2. Yuan, B.X.; Li, Z.H.; Su, Z.L.; Luo, Q.Z.; Chen, M.J.; Zhao, Z.Q. Sensitivity of Multistage Fill Slope Based on Finite Element Model. Adv. Civ. Eng. 2021, 2021, 6622936. [CrossRef]

3. Yuan, B.X.; Li, Z.H.; Chen, Y.M.; Ni, H.; Zhao, Z.Q.; Chen, W.J.; Zhao, J. Mechanical and microstructural properties of recycling granite residual soil reinforced with glass fiber and liquid-modified polyvinyl alcohol polymer. Chemosphere 2022, $286,131652$. [CrossRef]

4. Boulon, M. Basic features of soil structure interface behaviour. Comput. Geotech. 1989, 7, 115-131. [CrossRef]

5. Hu, L.M.; Pu, J.L. Testing and modeling of soil-structure interface. J. Geotech. Geoenvironm. Eng. 2004, 130, 851-860. [CrossRef]

6. Martinez, A.; Frost, J.D. The influence of surface roughness form on the strength of sand-structure interfaces. Geotech. Lett. 2017, 7, 104-111. [CrossRef] 
7. DeJong, J.T.; Westgate, Z.J. Role of Initial State, Material Properties, and Confinement Condition on Local and Global Soil-Structure Interface Behavior. J. Geotech. Geoenviron. Eng. 2009, 135, 1646-1660. [CrossRef]

8. Feligha, M.; Hammoud, F.; Belachia, M.; Nouaouria, M.S. Experimental Investigation of Frictional Behavior Between Cohesive Soils and Solid Materials Using Direct Shear Apparatus. Geotech. Geol. Eng. 2016, 34, 567-578. [CrossRef]

9. Huang, W.X.; Bauer, E.; Sloan, S.W. Behaviour of interfacial layer along granular soil-structure interfaces. Struct. Eng. Mech. 2003, 15, 315-329. [CrossRef]

10. Jeong, S.W.; Park, S.S. Effect of the Surface Roughness on the Shear Strength of Granular Materials in Ring Shear Tests. Appl. Sci. 2019, 9, 2977. [CrossRef]

11. Lei, W.; Mj, A.; Sz, D.; St, E.; Xiao, L.A. Investigation of microstructure of C-S-H and micro-mechanics of cement pastes under NH 4 NO 3 dissolution by 29 Si MAS NMR and microhardness. Measurement 2021, 185, 110019. [CrossRef]

12. Wang, L.; Guo, F.X.; Lin, Y.Q.; Yang, H.M.; Tang, S.W. Comparison between the effects of phosphorous slag and fly ash on the C-S-H structure, long-term hydration heat and volume deformation of cement-based materials. Constr. Build. Mater. 2020, 250, 118807. [CrossRef]

13. Wang, L.; Li, G.; Li, X.; Guo, F.; Tang, S.; Lu, X.; Haniff, A. Influence of reactivity and dosage of MgO expansive agent on shrinkage and crack resistance of face slab concrete. Cem. Concr. Compos. 2022, 126, 104333. [CrossRef]

14. Wang, L.; Zeng, X.; Yang, H.; Lv, X.; Guo, F.; Shi, Y.; Hanif, A. Investigation and Application of Fractal Theory in Cement-Based Materials: A Review. Fractal Fract. 2021, 5, 247. [CrossRef]

15. Lam, L.; Huang, L.; Xie, J.-H.; Chen, J.-F. Compressive behavior of ultra-high performance concrete confined with FRP. Compos. Struct. 2021, 274, 114321. [CrossRef]

16. Gomez, J.E.; Fiz, G.M.; Ebeling, R.M.; Dove, J.E. Sand-to-concrete interface response to complex load paths in a large displacement shear box. Geotech. Test. J. 2008, 31, 358-369.

17. Clough, G.W.; Duncan, J.M. Finite Element Analyses of Retaining Wall Behavior. J. Soil Mech. Found. Div. 1971, 97, 1657-1673. [CrossRef]

18. Desai, C.S.; Drumm, C.E.; Zaman, M.M. Cyclic testing and modeling of interfaces. ASCE J. Geotech. Eng. 1985, 111, 793-815. [CrossRef]

19. Evgin, E.; Fakharian, K. Effect of stress paths on the behaviour of sand-steel interfaces. Can. Geotech. J. 1996, 33, 853-865. [CrossRef]

20. Wu, Y.; Zhao, C.; Zhao, C.; Wang, Y.; Fei, Y. Effect of grout conditions on the mechanical behaviors of unloading sand-concrete interface for reinforcing bored pile foundation. Constr. Build. Mater. 2020, 243, 118218. [CrossRef]

21. Potyondy, J.G.; Potyondy, J.G. Skin friction between various soils and construction materials. Géotechnique 1961, 11, 339-353. [CrossRef]

22. Uesugi, M.; Kishida, H.; Tsubakihara, Y. Behavior of sand particles in sand-steel friction. Soils Found. 1988, 28, 107-118. [CrossRef]

23. Sharma, M.; Samanta, M.; Sarkar, S. A study on interface shear behaviour of soil nails from pullout and direct shear tests. Int. J. Phys. Model. Geotech. 2020, 20, 24-37. [CrossRef]

24. Taha, A.; Fall, M. Shear Behavior of Sensitive Marine Clay-Concrete Interfaces. J. Geotech. Geoenviron. Eng. 2013, 139, 644-650. [CrossRef]

25. Qian, J.G.; Gao, Q.; Xue, J.F.; Chen, H.W.; Huang, M.S. Soil and ribbed concrete slab interface modeling using large shear box and 3D FEM. Geomech. Eng. 2017, 12, 295-312. [CrossRef]

26. Kou, H.L.; Diao, W.Z.; Zhang, W.C.; Zheng, J.B.; Ni, P.P.; Jang, B.A.; Wu, C.Z. Experimental Study of Interface Shearing between Calcareous Sand and Steel Plate Considering Surface Roughness and Particle Size. Appl. Ocean Res. 2021, 107, 102490. [CrossRef]

27. Zhao, C.F.; Wu, Y.; Zhao, C.; Tao, G.X. Experimental Research on the Clay-Concrete Interface Shear Behaviors Considering the Roughness and Unloading Effect. In Proceedings of the GeoShanghai 2018 International Conference, Shanghai, China, 27-30 May 2018; pp. 522-530.

28. Zhao, C.; Zhang, R.; Zhao, C.F.; Wang, W.D.; Wang, Y.B. A Three-Dimensional Evaluation of Interface Shear Behavior between Granular Material and Rough Surface. J. Test. Eval. 2021, 49, 713-727. [CrossRef]

29. Zhang, M.Y.; Sang, S.K.; Wang, Y.H.; Bai, X.Y. Factors Influencing the Mechanical Characteristics of a Pile-Soil Interface in Clay Soil. Front. Earth Sci. 2020, 7, 11. [CrossRef]

30. Li, Y.H.; Lv, M.F.; Guo, Y.C.; Huang, M.S. Effects of the soil water content and relative roughness on the shear strength of silt and steel plate interface. Measurement 2021, 174, 109003. [CrossRef]

31. Su, L.J.; Zhou, W.H.; Chen, W.B.; Jie, X.X. Effects of relative roughness and mean particle size on the shear strength of sand-steel interface. Measurement 2018, 122, 339-346. [CrossRef]

32. Chu, L.-M.; Yin, J. Study on soil-cement grout interface shear strength of soil nailing by direct shear box testing method. Geomech. Geoeng. Int. J. 2006, 1, 259-273. [CrossRef]

33. Wang, X.; Wang, X.Z.; Zhu, C.Q.; Meng, Q.S. Shear tests of interfaces between calcareous sand and steel. Mar. Georesour. Geotechnol. 2019, 37, 1095-1104. [CrossRef]

34. Chen, X.B.; Zhang, J.S.; Xiao, Y.J.; Li, J. Effect of roughness on shear behavior of red clay-Concrete interface in large-scale direct shear tests. Can. Geotech. J. 2015, 52, 1122-1135. [CrossRef]

35. Sengoz, B.; Topal, A.; Tanyel, S. Comparison of pavement surface texture determination by sand patch test and 3D laser scanning Period. Polytech. Civ. Eng. 2012, 45, 73-78. [CrossRef]

36. Courard, L.; Nelis, M. Surface analysis of mineral substrates for repair works: Roughness evaluation by profilometry and surfometry analysis. Mag. Concr. Res. 2003, 55, 355-366. [CrossRef] 
37. Zhang, W.; Zhou, B.; Gu, X.; Dai, H. Probability distribution model for cross-sectional area of corroded reinforcing steel bars. J. Mater. Civ. Eng. 2013, 26, 822-832. [CrossRef]

38. Kim, M.K.; Sohn, H.; Chang, C.C. Active Dimensional Quality Assessment of Precast Concrete Using 3D Laser Scanning. Am. Soc. Civ. Eng. 2014, 2013, 622-628.

39. Dove, J.E.; Frost, J.D. Peak friction behavior of smooth geomembrane-particle interfaces. J. Geotech. Geoenviron. Eng. 1999, 125, 544-555. [CrossRef]

40. Yoshimi, Y.; Kishida, T. A Ring Torsion Apparatus for Evaluating Friction Between Soil and Metal Surfaces. Geotech. Test. J. 1981, 4, 145-152. [CrossRef]

41. Uesugi, M.; Kishida, H. Frictional resistance at yield between dry sand and mild steel. Soils Found. 1986, 26, 139-149. [CrossRef]

42. Chen, W.B.; Zhou, W.H.; Sadowski, L.; Yin, Z.Y. Metaheuristic model for the interface shear strength between granular soil and structure considering surface morphology. Comput. Geotech. 2021, 135, 104141. [CrossRef]

43. Wang, L.; Luo, R.Y.; Zhang, W.; Jin, M.M.; Tang, S.W. Effects of fineness and content of phosphorus slag on cement hydration, permeability, pore structure and fractal dimension of concrete. Fractals-Complex Geom. Patterns Scaling Nat. Soc. 2021, 29, 2140004. [CrossRef]

44. Wang, L.; Guo, F.X.; Yang, H.M.; Wang, Y.; Tang, S.W. Comparison of fly ash, PVA fiber, MgO and shrinkage-reducing admixture on the frost resistance of face slab concrete via pore structural and fractal analysis. Fractals-Complex Geom. Patterns Scaling Nat. Soc. 2021, 29, 2140002. [CrossRef]

45. Wang, L.; Jin, M.M.; Guo, F.X.; Wang, Y.; Tang, S.W. Pore structural and fractal analysis of the influence of fly ash and silica fume on the mechanical property and abrasion resistance of concrete. Fractals-Complex Geom. Patterns Scaling Nat. Soc. 2021, 29, 2140003. [CrossRef]

46. Huang, J.; Li, W.; Huang, D.; Wang, L.; Chen, E.; Wu, C.; Wang, B.; Deng, H.; Tang, S.; Shi, Y.; et al. Fractal Analysis on Pore Structure and Hydration of Magnesium Oxysulfate Cements by First Principle, Thermodynamic and Microstructure-Based Methods. Fractal Fract. 2021, 5, 164. [CrossRef]

47. Lin, N.; Guo, J.; Xie, F.; Zou, J.; Tian, W.; Yao, X.; Zhang, H.; Tang, B. Comparison of surface fractal dimensions of chromizing coating and P110 steel for corrosion resistance estimation. Appl. Surf. Sci. 2014, 311, 330-338. [CrossRef]

48. Liang, C.; Zhang, W. Fractal characteristic of pits distribution on 304 stainless steel corroded surface and its application in corrosion diagnosis. J. Wuhan Univ. Technol. Mater. Sci. Ed. 2007, 22, 389-393. [CrossRef]

49. Chen, X.; Zhou, J.; Ding, N. Fractal characterization of pore system evolution in cementitious materials. KSCE J. Mater. Civ. Eng. 2015, 19, 719-724. [CrossRef]

50. Xie, H.; Wang, J.; Xie, W. Fractal effects of surface roughness on the mechanical behavior of rock joints. Chaos Soliton Fractals 1997, 8, 221-252. [CrossRef]

51. Zhou, H.; Xie, H. Direct estimation of the fractal dimensions of a fracture surface of rock. Surf. Rev. Lett. 2003, 10, 751-762. [CrossRef]

52. Xu, Y.D.; Qian, C.X. Fractal characterization of corroded surface profile in reinforcing steel bars. Adv. Mater. Res. 2011, 163-167, 3118-3121. [CrossRef]

53. Wang, L.; He, T.S.; Zhou, Y.X.; Tang, S.W.; Tan, J.J.; Liu, Z.T.; Su, J.W. The influence of fiber type and length on the cracking resistance, durability and pore structure of face slab concrete. Constr. Build. Mater. 2021, 282, 122706. [CrossRef]

54. Li, L.G.; Feng, J.J.; Zhu, J.; Chu, S.H.; Kwan, A.K.H. Pervious concrete: Effects of porosity on permeability and strength. Mag. Concr. Res. 2021, 73, 69-79. [CrossRef]

55. Huang, B.T.; Wu, J.Q.; Yu, J.; Dai, J.G.; Leung, C.K.Y.; Li, V.C. Seawater sea-sand engineered/strain-hardening cementitious composites (ECC/SHCC): Assessment and modeling of crack characteristics. Cem. Concr. Res. 2021, 140, 106292. [CrossRef]

56. Zhou, J.Y.; Sun, Z.; Wei, B.; Zhang, L.W.; Zeng, P. Deflection-based multilevel structural condition assessment of long-span prestressed concrete girder bridges using a connected pipe system. Measurement 2021, 169, 108352. [CrossRef]

57. Zhou, J.Y.; Caprani, C.C.; Zhang, L.W. On the structural safety of long-span bridges under traffic loadings caused by maintenance works. Eng. Struct. 2021, 240, 112407. [CrossRef]

58. Zou, R.; Liu, F.; Xiong, Z.; He, S.H.; Li, L.J.; Wei, W.; Xiong, Z.; Lin, L.; Qiao, S.; Li, L.; et al. Axial performance of seawater sea-sand concrete columns reinforced with basalt fibre-reinforced polymer bars under concentric compressive load. J. Build. Eng. 2022, 47, 103828. [CrossRef]

59. Qu, F.; Li, W.; Wang, K.J.; Tam, V.W.Y.; Zhang, S.S. Effects of seawater and undesalted sea sand on the hydration products, mechanical properties and microstructures of cement mortar. Constr. Build. Mater. 2021, 310, 125229. [CrossRef]

60. Luo, Z.; Li, W.; Wang, K.; Shah, S.P.; Sheng, D. Nano/micromechanical characterisation and image analysis on the properties and heterogeneity of ITZs in geopolymer concrete. Cem. Concr. Res. 2022, 152, 106677. [CrossRef]

61. Dong, W.; Li, W.; Guo, Y.; Qu, F.; Wang, K.; Sheng, D. Piezoresistive performance of hydrophobic cement-based sensors under moisture and chloride-rich environments. Cem. Concr. Compos. 2022, 126, 104379. [CrossRef]

62. Yu, K.Q.; McGee, W.; Ng, T.Y.; Zhu, H.; Li, V.C. 3D-printable engineered cementitious composites (3DP-ECC): Fresh and hardened properties. Cem. Concr. Res. 2021, 143, 106388. [CrossRef]

63. Cai, Z.W.; Liu, F.C.; Yu, J.T.; Yu, K.Q.; Tian, L.K. Development of ultra-high ductility engineered cementitious composites as a novel and resilient fireproof coating. Constr. Build. Mater. 2021, 288, 123090. [CrossRef]

64. Ding, Y.; Yu, K.; Li, M. A review on high-strength engineered cementitious composites (HS-ECC): Design, mechanical property and structural application. Structures 2022, 35, 903-921. [CrossRef] 
65. Xiao, J.; Long, X.; Qu, W.J.; Li, L.; Jiang, H.B.; Zhong, Z.C. Influence of sulfuric acid corrosion on concrete stress-strain relationship under uniaxial compression. Measurement 2022, 187, 110318. [CrossRef]

66. Chandra, A.P.; Gerson, A.R. The mechanisms of pyrite oxidation and leaching: A fundamental perspective. Surf. Sci. Rep. 2010, 65, 293-315. [CrossRef]

67. Fan, Y.; Hu, Z.; Zhang, Y.; Liu, J. Deterioration of compressive property of concrete under simulated acid rain environment. Constr. Build. Mater. 2010, 24, 1975-1983. [CrossRef]

68. Xie, S.; Qi, L.; Zhou, D. Investigation of the effects of acid rain on the deterioration of cement concrete using accelerated tests established in laboratory. Atmos. Environ. 2004, 38, 4457-4466. [CrossRef]

69. Li, X.; Lin, X.; Lin, K.; Ji, T. Study on the degradation mechanism of sulphoaluminate cement sea sand concrete eroded by biological sulfuric acid. Constr. Build. Mater. 2017, 157, 331-336. [CrossRef]

70. O'Connell, M.; McNally, C.; Richardson, M.G. Performance of concrete incorporating GGBS in aggressive wastewater environments. Constr. Build. Mater. 2012, 27, 368-374. [CrossRef]

71. Chang, Z.T.; Song, X.J.; Munn, R.; Marosszeky, M. Using limestone aggregates and different cements for enhancing resistance of concrete to sulphuric acid attack. Cem. Concr. Res. 2005, 35, 1486-1494. [CrossRef]

72. De Belie, N.; Monteny, J.; Beeldens, A.; Vincke, E.; Van Gemert, D.; Verstraete, W. Experimental research and prediction of the effect of chemical and biogenic sulfuric acid on different types of commercially produced concrete sewer pipes. Cem. Concr. Res. 2004, 34, 2223-2236. [CrossRef]

73. Hughes, B.P.; Guest, J.E. Limestone and siliceous aggregate concretes subjected to sulphuric acid attack. Mag. Concr. Res. 1978, 30, 11-18. [CrossRef]

74. Xiao, J.; Qu, W.J.; Jiang, H.B.; Li, L.; Huang, J.; Chen, L. Fractal characterization and mechanical behavior of pile-soil interface subjected to sulfuric acid. Fractals-Complex Geom. Patterns Scaling Nat. Soc. 2021, 29, 2140010. [CrossRef]

75. Mahmoodian, M.; Alani, A.M. Effect of Temperature and Acidity of Sulfuric Acid on Concrete Properties. J. Mater. Civ. Eng. 2017, 29, 04017154. [CrossRef]

76. ISO-ISO16610-21; 2011-Geometrical Product Specifications (Gps)_Filtration-Part 21: Linear Profile Filters: Gaussian Filters. ISO: Geneva, Switzerland, 2011. Available online: https://www.iso.org/standard/50176.html(accessed on 1 December 2021).

77. Macek, W. Correlation between Fractal Dimension and Areal Surface Parameters for Fracture Analysis after Bending-Torsion Fatigue. Metals 2021, 11, 1790. [CrossRef]

78. Zhao, Z.H.; Lv, X.Z.; Wang, W.M.; Tan, Y.L. Damage evolution of bi-body model composed of weakly cemented soft rock and coal considering different interface effect. Springerplus 2016, 5, 19. [CrossRef]

79. Yin, Z.Z.; Zhu, H.; Xu, G.H. A study of deformation in the interface between soil and concrete. Comput. Geotech. 1995, 17, 75-92.

80. Gao, H.H.; Ma, B.J.; Singh, R.P.; Yang, H. Areal Surface Roughness of AZ31B Magnesium Alloy Processed by Dry Face Turning: An Experimental Framework Combined with Regression Analysis. Materials 2020, 13, 2303. [CrossRef] [PubMed] 